\title{
A CSÍKI-HAVASOK CSÁSZÁRMADÁR (Bonasa bonasia) ÁLLOMÁNYÁNAK VIZSGÁLATA
}

\author{
Szabó István \\ 530305 Miercurea Ciuc, Str. Tas vezér Nr. 13., Jud. Harghita, Romania
}

\begin{abstract}
SZABÓ I.: INVESTIGATION ON HAZEl GRouse (Bonasa bonasia) POPUlation ON CSIKI Mountain. Hungarian Small Game Bulletin 12: 155-191. http://dx.doi.org/10.17243/mavk.2014.155

The investigation for habitat use of Hazel Grouse has shown that the individuals of this species mostly occur in the area at the edges of stand structural forests and close to them in clearings. During their nesting time, they preferred the shrub layer and the edges of forest stands. In the early autumn they also appeared most often in these areas and not far from watery. When the leaves fell, the undergrowth diminished and the foliage disappeared together with available food and cover. At the end of autumn Hazel Grouse disappeared from the area. The birds preferred the roads and the variable shrub edges (IVLEV-index Plot I. - 2001: 0,42; 2002: 0,17; 2009: 0,66; Plot II. - 2001: 0,52; 2002: 0,09) near the roads. They showed high preference for the areas covered by shrub in the clearings. (IVLEV-index Plot I. - 2001: 0,13; 2002: 0,47; 2009: 0,34; Plot II. - 2001: 0,57; 2002: 0,83). The zone of watery area (IvLEV-index Plot I. - 2001: 0,52; 2002: 0,54; 2009: 0,06; Plot II. - 2001: 0,77; 2002: 0,73 ) had the maximum values. On the whole, well-structured mosaic-like habitat types are favourable for the Hazel Grouse. This means that they prefer the vertical and horizontal habitat diversity, which provides them with cover and available food. Factors that endanger the Hazel Grouse in Csíki Mountains are as follows: pasture, driving of animals, the increasing logging, building of roads and weekend houses, wind, and predation. The influence of shooting is small. To keep Hazel Grouse in Csíki Mountains we have to ensure that their preferred habitats are undisturbed. Ethical shooting and the control of the wild boar and key predators also must be ensured.
\end{abstract}

KULCSSZAVAK: császármadár, Csíki-havasok, élőhely-preferencia, vadvédelem KEYWORDS: Hazel Grouse, Csiki Mountain, habitat preference, game conservation

\section{BEVEZETÉS}

Kutatásaimat Hargita megye területén 2001 és 2002 között, illetve 2009 és 2010 között végeztem. A felmérések célja a Csíki-havasok császármadár állományának vizsgálata volt. A császármadár vagy egyszerủen mogyorós tyúk a fajdfélék (Tetraonidae) családjába tartozik. Erdélyben ez a leggyakoribb fajdféle, amely a mi közvetlen környezetünket is benépesíti. A császármadár populációinak méretét számos tényező befolyásolhatja. Egyik a reprodukciókat veszélyeztető hatás, a fészekaljak megsemmisülése. A tojások jelentős része nem jut el a kikelés stádiumáig. Ez nagymértékben a ragadozók fészekrabló tevékenységének következménye. A másik negatív hatás az antropogén tényezők jelenléte, legeltetés, erdővágás, turizmus okozta károk. Rendkívül fontos a faj életmódjának minél pontosabb megismerése, hogy ezeket a hatásokat a lehető legszélesebb körben ki tudjuk küszöbölni. Ez a folyamat nemcsak vadvédelmi érdekeket, hanem az emberi jövő biztosítását célzó irányzat kell, hogy legyen.

Jelen munkámmal az időbeli hiányosságokat szeretném pótolni. Kutatásaim fő célja a császármadár minél szélesebb körü megismerése, a kisebb-nagyobb populációk 
tanulmányozása, tekintettel azok eltérő és nagyon zárkózott viszonyaira. Megvizsgáltam az ökológiai tényezőket, a helyi adottságokat és lehetőségeket, mindezek szigorú figyelembevételével végeztem munkámat. Természetesen nem állítom, hogy csupán egy kutatási területen folytatott vizsgálatok alapján egész Hargita megye területére érvényes átfogó képet tudok adni, de mivel a kutatási területen található adatok fellelhetők az egész megye területén is, így az elkövetkezendő fejezetekben ismertetésre kerülő adatok a megye egész területére érvényesek lehetnek.

A faj romániai állománya 16-24 ezerre becsült. Elterjedésére vonatkozóan az alacsonyabban fekvő területektől, 300 m-es t. sz. f. magasságtól egészen a 800-1300 méteres magasságig megtalálható. Leggyakoribb előfordulása a 800 és 1300 m-es tengerszint feletti régiók övezete. A különböző hegyvonulatokban megközelítőleg a következő magasságokban található: Radnai havasok 1550 m, Görgényi-havasok 13001500 m között. A Kelemen havasokban szintén 1300 m-es t. sz. f. magasságtól az 1380 m-es magasságig. Az erdélyi Érchegységben akár az 1800 m-es magasságig is felhúzódhatnak. A Fogarasi havasokban az 1650 m-es magasságig ismert előfordulásuk, állományuk azonban a Maros alsó folyásánál, ÓRadna és a Szoborsín vidékén, Székelyföldön és a bánsági lombos erdőkben a legnagyobb.

Már ezekből az adatokból is következik, hogy a császármadár Erdélyben a gazdag aljnövényzetü hegyvidéki vegyes, vagy lomberdőkben él, de felhúzódik a fenyőfélék felső régiójába, gyakran azok felső határáig is. Kedveli még a láperdőket is (COTTA et al, 2001).

Biztos tojásköltési-kotlási helyek már a régebbi időkből ismertek. Így már 1914-ben feljegyezték a makfalvi erdőkben (Maros megye) előfordulásukat, mi több június 8-án egy földön talált fészekaljról szól a feljegyzés. A tojások száma 6 darab volt. Királyfürdő közelében (Hargita megye) 1941-ben 2 darab tojást jeleztek az akkori feljegyzések. A Bodoki-hegységben (Kovászna megye) 1975. június 23-án egy fészekben 4 darab tojást találtak. A Kelemen-havasokban (Maros megye területén) 1980. június 19-én 3 alig éppen kirepült fiókát figyeltek meg. A magashegyvidéki előfordulásukat bizonyítja egy 1988-as Retyezát hegységi (Hunyad megye) megfigyelés is (KLEMM \& KOHL, 1988).

Napjainkban a fajnak Hargita megye területén más elöfordulási helyei is ismertek, a fent említett egy-két hely mellett, azonban a környezeti tényezők változása (nagyfokú széldöntések és széltörések), valamint a különböző zavaró tényezők hatására (erdökitermelések, turistaforgalom, építkezések stb.) ez a fajdféle mára nagyon elszigetelödött. Az amúgy is rejtett életmódot fojtató császármadár mindezek hatására még inkább háttérbe szorult, a meglévő populációk életéről keveset tudunk, vagy jóformán nem is ismerjük.

1999-2009 közötti időszakban a rendszerváltás következtében az addig egységesen államilag kezelt erdők, legelők és mezőgazdasági területek visszakerültek jogos tulajdonosaik birtokába, kezelésébe. A változások után a jelenleg is érvénybe levő törvények értelmében a tulajdonosok eladták erdeiket vagy saját maguk termelték-termelik ki a fát a megélhetés vagy fennmaradás érdekébe. Mindezek következtében odajutottunk, hogy szórványosan egyazon időben nap, mint nap „szól” a láncfürész, erőgépek és a kitermelő munkások hangoskodása veri fel erdeink csendjét, nyugalmát. Az addig tömbösített, jól megszervezett erdőhasználati munkálatok megszüntek, helyettük szervezetlen, szétszórt folyamatosan müködő erdőkitermelések történtek, állandó zavarást és folytonos veszélyt jelentve az itt élő vad számára. Az amúgy is nagyon érzékeny császármadár kényesen reagál e jelenségekre, szétszóródik, időszakosan fészkelővé válik, vagy végérvényesen eltűnik e területekről valamint azok közvetlen vagy távolabbi szomszédságából. Mindezen okokból kutatásaimban az alábbi kérdésekre kerestem a választ:

- A császármadár állományalakulása az 1999-2009 közötti időszakban a tulajdon és gazdaságszerkezet változás függvényében. 
- A császármadár élőhely-használatának vizsgálata a dürgés, a fészkelés és telelés időszakában.

- A császármadárral kapcsolatos újabban fellépett lokális védelmi problémák vizsgálata és ezek értékelése, úgymint

az erdők tulajdonosváltásából és használatából eredő változások, a legeltetés hatása, építési munkák növekedésének hatása.

\section{A VIZSGÁLATI TERÜLET}

A császármadarat elterjedése széles spektrumot mutat. A francia Alpoktól Japánig megtalálható. Napjainkban 5 alfajt tartanak számon. A Kárpátokban, így Romániában a Bonasa bonasia rupestris fordul elő. A nyugati, keleti és déli Kárpátokban él fenyvesekben és nyírelegyes erdőkben. A Hargita hegység vonulatain a fenyvesekben, páfrányos bükkösökben, főként elegyes erdőkben található.

Romániai elterjedésére vonatkozóan csak a Hargita megyei populációk jelenlegi elhelyezkedésére térnék ki. Napjainkban a császármadár legnagyobb számban a turizmus és az erdőgazdasági munkák által kevésbé zavart területeken fordul elő. Évszakonként megfigyelhető egy bizonyos migráció egy adott biotópon belül a fent említett zavaró tényezők hatására, illetve azok intenzitásának függvényében. Napjainkban a császármadár populációk biotópjának túlnyomó részét természetes eredetü vegetáció borítja. Az ősi erdős területek egyre inkább szükülnek az erdők nagyarányú kitermelésének következtében. Szerencsére az „Ösi Hargitán” még nagyon sok őshonos erdőtársulás, erdőtípus található a benne őshonos fa és lágyszárú növényfajokkal, melyeket az éghajlat, a talajtípus, a vízgazdálkodási viszonyok határoznak meg.

\subsection{Az I. mintaterületen található erdőtípusok}

Az I. mintaterület kitüzésekor $3 \times 1,8$ km-es egységet, azaz 540 ha-t tekintettünk át, amelynek császármadár által ténylegesen elfoglalt területe 2001-ben és 2002-ben 65,9 hektár volt, 2009-ben ez lecsökkent 45,7 hektárra. E területeket érintő erdőrészletek jellemzését az alábbiakban adhatjuk meg.

A Szécseny 16-os számú erdőtag összterülete 20,2 ha. Földrajzi besorolása: G.F.-1-1A, 4B. Talajtípusa: T.S.-3333, barna erdőtalaj. A felszín hullámos, keleti kitettséggel, 27 fokos lejtésszöggel. Tengerszint feletti magassága 890-1000 m között váltakozik. Az anyakőzet részlegesen látszik, helyben maradt kidőlt fákkal. A köveket mindenütt moha (Polystrichum commune) borítja. Az alomtakaró folytonosan szabályos, Asperula-Oxalis talajjelző növényzettel. Az állomány eredete: természetes felújulás és aránylag egykorú. Az állományon belüli fajok aránya: 70\% közönséges lucfenyő (Picea abies), 30\% közönséges jegenyefenyő (Abies alba). Cserjeszintet alkotó fajok: közönséges mogyoró (Corylus avellana), sóskaborbolya (Berberis vulgaris), egybibés galagonya (Crataegus monogyna), földi szeder (Rubus fruticosus), hamvas szeder (Rubus caesius), málna (Rubus idaeus). Az erdőszegély mentén és a jelenlévő tisztáson (Bilibók puszta) szórványosan fordul elő a gyepürózsa (Rosa canina), közönséges boróka (Juniperus communis).

A Szécseny 19/A számú erdötag összterülete 19,3 ha. Földrajzi besorolása: G.F.-1-1A, 4B. Talajtípusa: T. S. - 3332, barna erdőtalaj. A felszín közepesen hullámos, északkeleti kitettséggel, 26 fokos lejtésszöggel. Tengerszint feletti magassága 890-1100 m között váltakozik. Az anyakőzet részlegesen látszik, helyben maradt kidőlt fákkal. A köveket 
mindenütt moha (Polystrichum commune) borítja. Az alomtakaró folytonosan szabályos, Oxalis-Soldanella talajjelző növényzettel. Az állomány eredete: természetes felújulás és aránylag egykorú. Az állományon belüli fajok aránya: 80\% közönséges lucfenyő (Picea abies), 20\% közönséges jegenyefenyő (Abies alba). Cserjeszintet alkotó fajok: közönséges mogyoró (Corylus avellana), földi szeder (Rubus fruticosus), hamvas szeder (Rubus caesius), gyepürózsa (Rosa canina).

A Szécseny 19/B számú erdőtag összterülete 1,1 ha. Földrajzi besorolása: G.F.-1A,-4B. Talajtípusa: T.S. 3332, barna erdőtalaj. A felszín hullámos, északi kitettséggel, 27 fokos lejtésszöggel. Tengerszint feletti magassága $1100 \mathrm{~m}$. Az anyakőzet részlegesen látszik, ritkán előforduló helyben maradt kidőlt fákkal. A kövek nagy részét moha (Polystrichum commune) borítja. Az alomtakaró folytonosan szabályos, Oxalis-Soldanella talajjelző növényzettel. Az állomány eredete: természetes felújulás és aránylag egykorú. Az állományon belüli fajok aránya: 80\% közönséges lucfenyő (Picea abies), 20\% közönséges jegenyefenyő (Abies alba). Cserjeszintet alkotó fajok: közönséges mogyoró (Corylus avellana), földi szeder (Rubus fruticosus), hamvas szeder (Rubus caesius), málna (Rubus idaeus). Az erdőszegély mentén egybibés galagonya (Crataegus monogyna), és elszórtan közönséges boróka (Juniperus communis), gyepürózsa (Rosa canina).

A Szécseny 20 számú erdötag összterülete 22,1 ha. Földrajzi besorolása: G.F. 1-1A,4B. Talajtípusa: T.S. - 3332, barna erdőtalaj. A felszín hullámos, észak-keleti kitettséggel, 27 fokos lejt szöggel. Tengerszint feletti magassága 900-1050 m között váltakozik. Az anyakőzet részlegesen látszik, szórványosan előforduló helyben maradt kidőlt fákkal. A köveket mindenütt moha borítja (Polystrichum commune). Az alomtakaró folytonosan szabályos, Oxalis-Soldanella talajjelző növényzettel. Az állomány eredete természetes felújulás és aránylag egykorú. Az állományon belüli fajok aránya: $80 \%$ közönséges lucfenyő (Picea abies), 20\% közönséges jegenyefenyő (Abies alba). A területet nyugaton határoló gerinc északkeleti oldalát felhagyott erdei út szeli át, tengerszint felett 1000 m-en húzódik. Az út két oldalán elegyfajokat találunk: közönséges nyír (Betula pendula), gyertyán (Carpinus betulus), bükk (Fagus sylvatica), elszórtan rezgőnyár (Populus tremula). Az erdőtag délnyugati részén egy foglalt kút található, ettől északkeleti irányban vízmosás, állandó patakmederrel. A meredek oldalon a csapadék nagy sebességgel folyik le, nagyobb csapadékmennyiség esetén a lejtő teljes szélességében. Ezen a területen elöfordul a mézgás éger (Alnus glutinosa). Az elegyfajok kisebb-nagyobb csoportokban fordulnak elő az állományalkotó fafajok mellett, részarányuk nem éri el a 30\%-ot. Cserjeszintet alkotó fajok: közönséges mogyoró (Corylus avellana), málna (Rubus idaeus), sóskaborbolya (Berberis vulgaris), egybibés galagonya (Crataegus monogyna), földi szeder (Rubus fruticosus), hamvas szeder (Rubus caesius). Az erdőtag délnyugati oldalán elterülő erdei tisztáson (Bilibók puszta) szórványosan megjelenik a közönséges boróka (Juniperus communis) és a gyepürózsa (Rosa canina). Az erdőszegély 1015 m széles sávjában elegyfajként megjelent a bükk (Fagus sylvatica), mint újulat.

A Szécseny 22/ A számú erdötag összterülete 14,6 ha. Földrajzi besorolása: G.F.1-A, 4B. Talajtípusa: - T.S. 3332, barna erdőtalaj. A felszín közepesen hullámos, délkeleti kitettséggel, 27 fokos lejtésszöggel. Tengerszint fölötti magassága 950-1150 m között váltakozik. Az anyakőzet jól megfigyelhető, helyben maradt kidőlt, letörött fákkal. A köveket 30 - 40 \%-os arányban moha borítja (Polystrichum commune). Az alomtakaró folyamatosan szabályos, Asperula-Dentaria talajjelző növényzettel. Az állomány eredete természetes felújulás, 50\%-os lucfenyő (Picea abies) és 50\%-os bükk (Fagus sylvatica) állományalkotó fafajokkal. Az I - es számú biotóp ezen erdőtagját északról, keletről és délkeletröl mintegy 50 - 55 fokos lejtésü völgy határolja. A patak a biotópot megkerüli északkeleti, majd hirtelen 


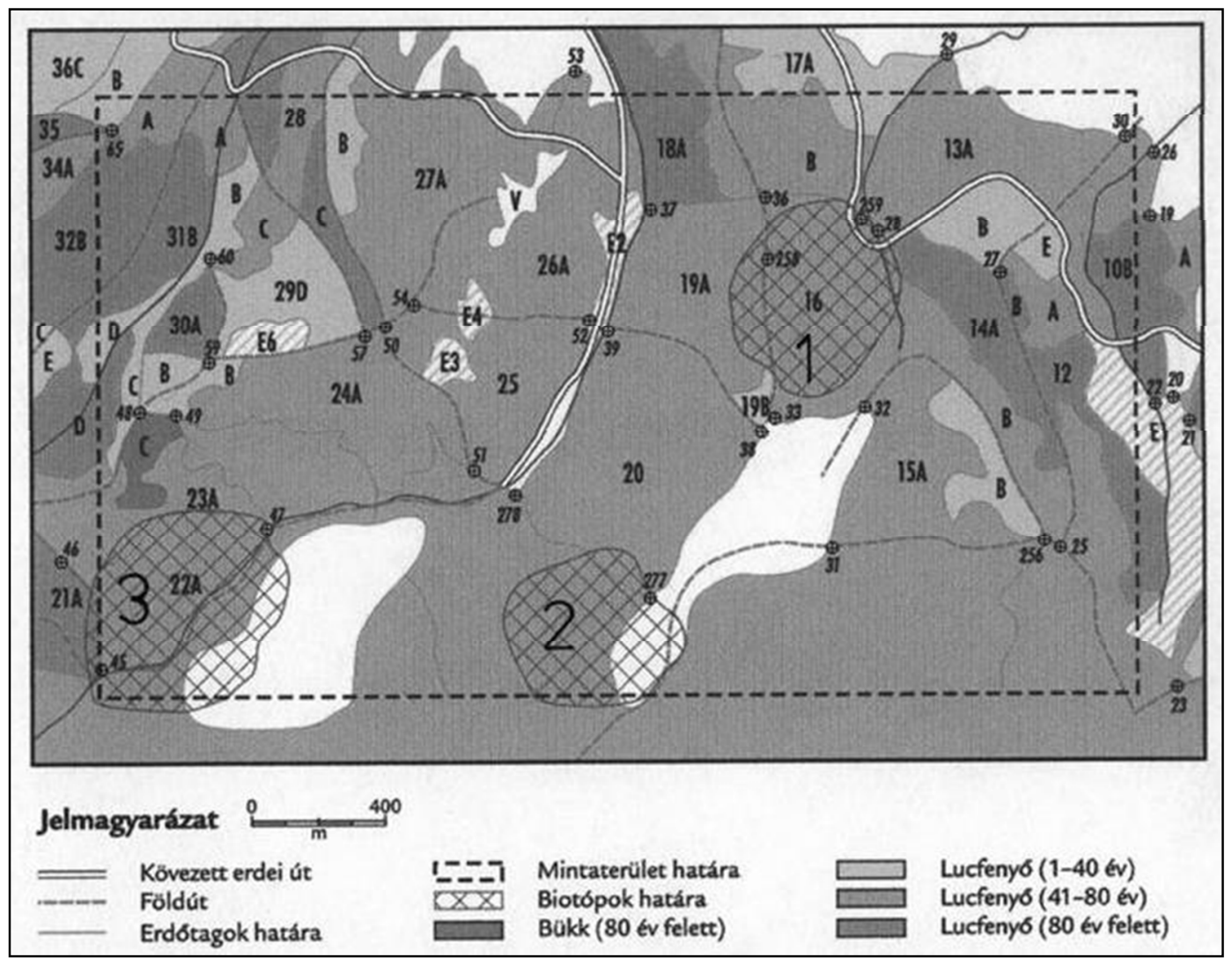

1. térkép: Az I. számú mintaterület térképe

Map 1: Map of the No. Plot I.

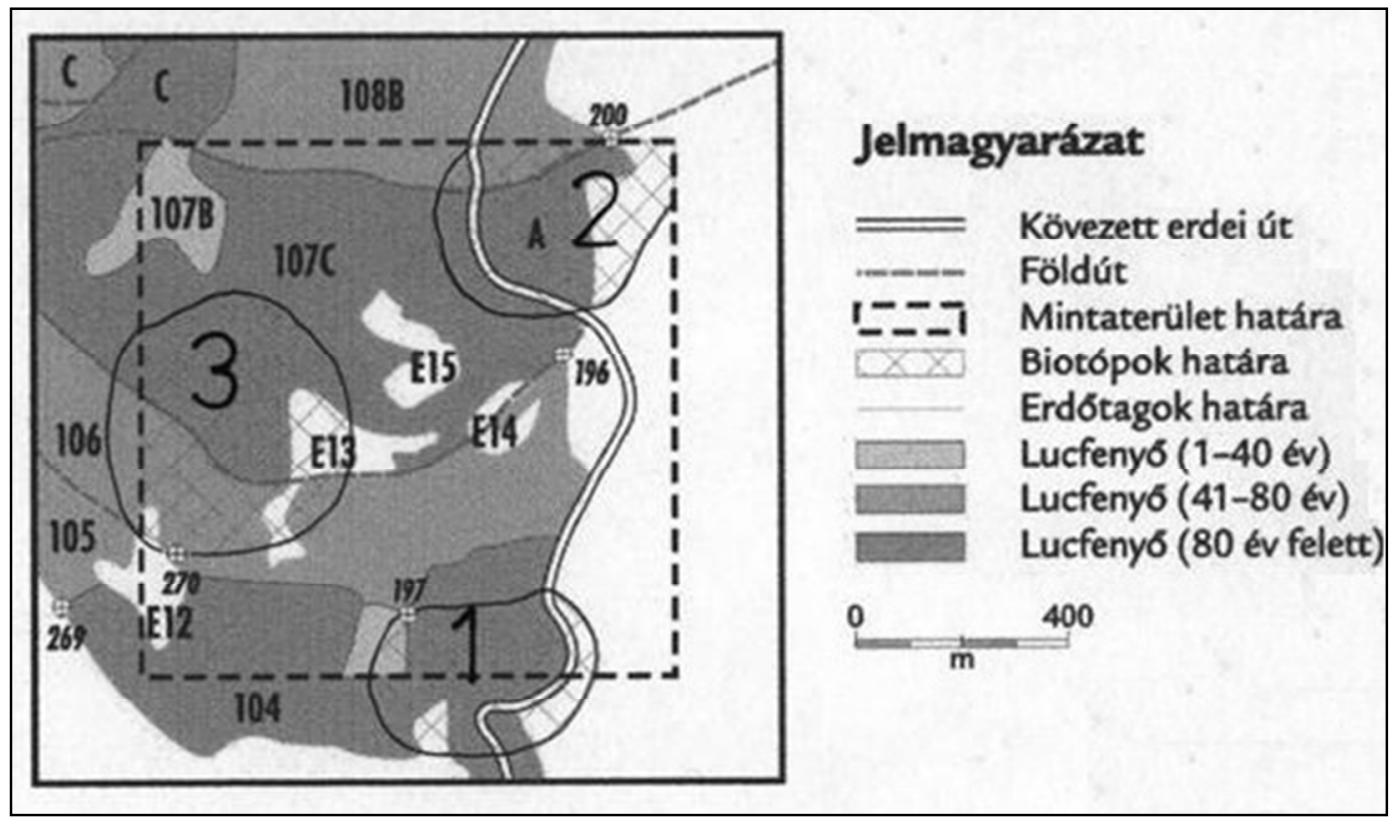

2. térkép: Az II. számú mintaterület térképe

Map 2: Map of the No. Plot II. 
fordulattal dél, délnyugati irányba. A széles patakmederre északnyugati irányban meröleges folyású patak szük völgye torkollik. Szűk út kíséri a mellékpatakot egészen a kőgörgeteges forrásvidékig. A forrásvidék a biotóp északkeleti csücskében található, környékének alja állandóan tocsogós. A vizsgált terület délen egy nagyméretü erdei tisztással határos (Hirtelenpuszta), amelynek nyugati peremén megközelítőleg rétegvonalban $(950 \mathrm{~m})$ tengerszint fölötti magasságban egy $2,75 \mathrm{~m}$ széles erdei út húzódik. A vizsgált terület növénytakarója igen változatos. Az állományalkotó fafajok mellett mint elegyfaj jelen van a közönséges nyír (Betula pendula), gyertyán (Carpinus betulus), hamvas éger (Alnus incana), madárberkenye (Sorbus aucuparia), erdei vadalma (Malus sylvestris), hegyi juhar (Acer pseudoplatanus),magas kőris (Fraxinus excelsior), jegenyefenyő (Abies alba), rezgő nyár (Populus tremula), mézgás éger (Alnus glutinosa) és a kecskefüz (Salix caprea). Ami a cserjeszintet illeti szórványosan jelen van a málna (Rubus idaeus), elszórtan vagy csoportosan a hamvas szeder (Rubus caesius), földi szeder (Rubus fruticosus). Az út mentén a cserjeszintben előfordul nagy gyakorisággal a fekete bodza (Sambucus nigra). Szórványosan megtalálható a bibircses kecskerágó (Euonymus verrucosus), veresgyürü som (Cornus sanguinea) és nagy mennyiségben van jelen a vizsgált területen a közönséges mogyoró (Corylus avellana) is. Az idős fák törzsén elégé ritkán, de elöfordul a borostyán (Hedera helix). A Hirtelen pusztáján szórványosan jelen van a közönséges boróka (Juniperus communis) és a gyepürózsa (Rosa canina).

\subsection{A II. mintaterületen található erdőtípusok}

Az II. mintaterület kitüzésekor $1 \times 1$ km-es egységet, azaz 100 ha-t tekintettünk át, amelynek császármadár által ténylegesen elfoglalt területe 2001-ben, 2002-ben és 2009-ben 40,40 hektár volt. E területeket érintő erdőrészletek jellemzését az alábbiakban adhatjuk meg.

A Piricske 104-es számú erdötag; összterülete 16,7 Ha. Földrajzi besorolása: G.F.- 21B. Talajtipusa: 3333, barna erdőtalaj. A felszín összefüggően hullámos, északkeleti kitettséggel, 26 fokos lejtésszöggel. Tengerszint feletti magassága 950-1100 m között váltakozik. Az anyakőzet részlegesen látszik, gyakori helyben maradt, kidőlt fákkal. A köveket mindenütt moha (Polystrichum commune) borítja. Az alomtakaró folytonosan szabályos, Asperula-Oxalis talajjelző növényzettel. Az állomány eredete természetes felújulás és aránylag egykorú. Az állományon belüli fajok aránya: 60\% - közönséges lucfenyő (Picea abies), $40 \%$ jegenyefenyő (Abies alba). A vizsgált erdőtag délkeleten határos egy több hektáros nagyságú bozótos kaszálóval. Ezen a területen kisebb-nagyobb csoportokban jelen van a közönséges nyír (Betula pendula), a gyertyán (Carpinus betulus), hegyi juhar (Acer pseudoplatanus). Nagyobb részarányba jelen van a bükk (Fagus sylvatica), elszórtan a kecskefüz teszi változatosabbá az erdőtag szomszédos délkeleti területeit. A II - es számú biotópot északról és nyugatról mintegy 30-35 fokos lejtésű magas hegygerincek határolják. A patak javarészt megkerüli ezeket a hegytömböket és északkeleti irányba folyik az erdőtagtól északra. Az erdőtag délkeleti csücskében, 1000 m tengerszint fölötti magasságon erdei autóút húzódik. Az autoút mentén két oldalt a cserjeszintben megtalálható a fekete bodza (Sambucus nigra), hegyi juhar (Acer pseudoplatanus), a közönséges nyír (Betula pendula), bükk (Fagus sylvatica), elszórtan a mézgás éger (Alnus glutinosa) és nagyon gyakori a közönséges mogyoró (Corylus avellana) tömeges előfordulása. Nagyon ritkán de előfordul az egybibés galagonya (Crataegus monogyna), a fanyarka (Amelanchier ovalis) és a földi szeder (Rubus fruticosus). Az erdőtag délen egy bozótos erdei legelővel határos, ahol tömegesen előfordul a közönséges mogyoró (Corylus avellana). A kis patak mely északnyugatról délkeleti irányba szegélyezi ezt a területet, állandóan tocsogós területével otthont biztosít a mézgás égernek (Alnus glutinosa) és a rezgő nyárnak. (Populus tremula). A térségben elszórtan megjelenik a 
fekete bodza (Sambucus nigra), a földi szeder (Rubus fruticosus) és itt-ott tarkállik piros termésével a gyepürózsa (Rosa canina).

A Piricske 105-ös számú erdötag összterülete 8,9 ha, földrajzi besorolása G.F. 2 - 1B. Talajtípusa: T.S. 3333, barna erdőtalaj. A felszín hullámos, északkeleti kitettséggel, 26 fokos lejtésszöggel. Tengerszint feletti magassága 1000-1300 m között váltakozik. Az anyakőzet eléggé jól látszik, gyakori helyben maradt kidőlt fákkal. A köveket nagy általánosságban moha (Polystrichum commune) borítja. Az alomtakaró szabályos, Asperula-Oxalis talajjelző növényzettel. Az állomány eredete természetes felújulás és aránylag egykorú. Az állományon belüli faj jelenlét: - 70\% közönséges lucfenyő (Picea abies), 30\%-ban jegenyefenyő (Abies $a l b a)$. Az erdőtag délnyugati oldalon több hektáros nagyságú bozótos beerdősödött legelövel határos, melynek szélén jelentős mennyiségben találhatók: Corylus avellana, Sambucus nigra, Rubus idaeus, Rosa canina. Az erdőtag szomszédságában elszórtan előfordul az Amelanchier ovalis és a Berberis vulgaris. Nagyon fontos említést tenni a bükkről (Fagus sylvatica), mint fontos elegyfajról, a közönséges gyertyánról (Alnus glutinosa) és a közönséges nyírfáról (Betula pendula). A vizsgált erdőtag szomszédságában északkeleten és keleten más erdőtagok helyezkednek el.

A Piricske 106-os számú erdötag összterülete 28,0 ha. Földrajzi besorolása: G.F. -2 1B. Talajtípusa: T. S. - 3333. barna erdőtalaj. A hegyoldal felszíne hullámos, 26,6 fokos lejtésszöggel. Tengerszint fölötti magassága 1050-1300 m között váltakozik. Az anyakőzet látszik, nagyon gyakori helyben maradt kidölt fákkal. A köveket itt is moha (Polystrichum commune) borítja. Ezen erdőtag esetében is az alomtakaró folytonosan szabályos, AsperulaOxalis talajjelző növényzettel. Az állomány eredete természetes, nagyjából egykorú a fafajok aránya a következő: 70\% közönséges lucfenyő (Picea abies), 30\% jegenyefenyő (Abies alba). A cserjeszint ezen erdőtag esetében már jóval szegényesebb, a fontosabb állományalkotó fajok alatt előfordul a földi szeder (Rubus fruticosus), itt-ott a málna (Rubus idaeus), valamint nagyon ritkán az erdei iszalag (Clematis vitalba). Kimondottan elegyfajként jelenik meg a közönséges nyír (Betula pendula), a bükk (Fagus sylvatica), valamint elszórtan egy-egy gyertyán (Carpinus betulus). Sokkal változatosabb a biotópot alkotó fafajok elegyaránya az erdőtagot keleten határoló erdei út két oldalán. Nagy számban van jelen a Fagus sylvatica, Acer pseudoplatanus, Betula pendula és a Carpinus betulus. Elenyésző számban megtalálható a Malus sylvestris, a Sorbus aucuparia és a Populus tremula, igaz szálanként. Az erdészeti út mentén a Rubus idaeus, Sambucus nigra és a kimondottan jelentős mennyiségben megtalálható Corylus avellana fordul elő. A délkeleti kitettségü, beerdősödött kaszálón megtalálható a Juniperus communis, a Rosa canina és elszórtan a Berberis vulgaris. Az erdőtag közeli szomszédságában egy foglalt kút található, ettől északkeleti irányban patakmeder található. Az egész térség vizenyős, ennek köszönhetően a térségben jelen van az Alnus glutinosa, a Salix cinerea és a Salix caprea.

A Piricske 107/A számú erdőtag összterülete 5,2 ha. Földrajzi besorolása: G.F. -2-1B, talajtípusa T.S. 3333, barna erdőtalaj. A hegyoldal felszíne hullámos, északnyugati kitettséggel, 26 fokos lejtésszöggel. Tengerszint feletti magassága $980 \mathrm{~m}$. Az anyakőzet nem annyira látható, mint az előző erdőtagok esetében. A nagyobb kövek szintén mohával (Polytrichum commune) borítottak. Az alomtakaró folytonosan szabályos, Asperula-Oxalis talajjelző növényzettel. Az állomány eredete természetes felújulás és aránylag egykorú. Az állományon belüli faj jelenlét: 60\% közönséges lucfenyő (Picea abies), 40\% jegenyefenyő (Abies alba). Az állományalkotó fafajok mellett megtalálható elegyfajként a bükk (Fagus sylvatica), a gyertyán (Carpinus betulus), nagyon szórványosan van jelen a közönséges nyír (Betula pendula). Az erdőtag délnyugaton határos az 1000 m-n húzódó erdei autóúttal, melynek mentén több méteres hosszúságban megtalálható a közönséges mogyoró (Corylus avellana), magasra nött sürü málna (Rubus idaeus) és a földi szeder (Rubus fruticosus). A 
felsorolt fafajok és cserjefajok mellett megtalálható még a rekettyefüz (Salix cinerea), kecskefüz (Salix caprea), és a keleti kaszálóval határos részeken elöfordul a közönséges borsika (Juniperus communis), gyepürózsa (Rosa canina).

A Piricske 107/B számú erdötag összterülete 3,6 ha. Földrajzi besorolása: G.F. -2-1B. A hegyoldal felszíne közepesen hullámos, déli kitettséggel, 31 fokos lejtésszöggel. Tengerszint feletti magassága 1150-1200 m között váltakozik. Az anyakőzet látszik, a köveket mindenütt moha (Polytrichum commune) borítja. Az alomtakaró nem egybefüggő, nagyon vékony, Asperula-Oxalis talajjelző növényzettel. Az állomány eredete természetes felújulás, szinte egykorú. A fafajok aránya 60\% lucfenyő (Picea abies), 20\% jegenyefenyő (Abies alba), 20\% bükk (Fagus sylvatica). A cserjeszintet alkotó fajok közül említésre méltó a mogyoró (Corylus avellana) és a földi szeder (Rubus fruticosus). Jelentős a Fagus sylvatica újulat, amely között nagy számban fordul elö a málna (Rubus idaeus).

A Piricske 107/C sz. erdötag összterülete 40,1 ha. Földrajzi besorolása: G.F. -2-1B. A hegyoldal felszíne közepesen hullámos, keleti kitettséggel, 26 fokos lejtésszöggel. Tengerszint feletti magassága 1000-1300 m között váltakozik. Az anyakőzet részben látszik, nagyon gyakori helyben maradt kidölt fákkal. A köveket részben moha (Polytrichum commune) borítja. Az alomtakaró folytonosan szabályos, Asperula-Oxalis talajjelző növényzettel. Ebben az esetben is elmondható az állomány eredetéröl, hogy természetes felújulás következtében keletkezett és aránylag egykorú. Az állományon belüli fajok aránya: 60\% lucfenyő (Picea abies), 40\%-ban jegenyefenyő (Abies alba). Szálanként vagy nagyon kis csoportokban a bükk (Fagus sylvatica) és a gyertyán van jelen, mint elegy fafaj. Kimondott cserjeszintet nem lehet emlegetni, kivételt képez a két erdei tisztással közvetlenül határos erdőszegély. Ezen a területen jelentős a Fagus sylvatica felújulás, közötte megtalálható a málna (Rubus idaeus ), a földi szeder (Rubus fruticosus).

A tagoltságnak köszönhetően a vizsgált területek lágyszárú növénytakarója is igen változatos. A növények felsorolásánál külön kitérek azon fajokra, melyek létfontosságúak a császármadár táplálkozásának szempontjából. A vizsgált két biotóp sokban hasonlít egymásra, éppen ezért sok hasonlatosság van a növénytársulások között is. Azonosításukat, besorolásukat a terepen növényhatározók segítségével végeztem a felhasznált irodalom útmutatásai alapján.

A biotópok középpontját Dryopteris filix mas, Asperula odorata alkotja. Különös fontossággal bír a Polygonatum odoratum, Melampyrum arvense és a Majanthenum bifolium. Érdekes módon nagy foltszerüen elterülő egységekben van jelen az Urtica dioica. Azon területeken ahol a talaj nagyobb vízmennyiséget tartalmaz, jelen van a Matricaria chamomilla, Trientalis europaea, Polytrichum commune. Nagy mennyiségben Lonicera sp., Clematis vitalpa, Oxalis acetosella és Pyrola rotundifolia van jelen. Az erdészeti út mentén Genista tinctoria, Betonica officinalis, Stellaria holostea teszi változatossá a biotópot. Nem nagy mennyiségben szövi át a lágyszárú növényeket a Ranunculus repens. Foltszerü elhelyezkedésủ a Petasites albus. Az út mentén továbbá megtalálható még a Melampyrum nemorosum, Filipendula vulgaris, Galium verum, Stahys recta, Melica uniflora, Dactylis glomerata. A déli kitettségü területeken megtalálható növényzet: Geranium sanguineum, Melampyrum nemorosum, Trifolium medium, Veronica hederofilia, Ranunculus polyanthemus, Hypericum perforatum, Achillea millefolium, Melica uniflora, Hieracium sylvaticum. Az I-es biotópot alkotó erdőtagok, a részletes leírásokban ismertetett tisztásokkal határosak. Ezen övezetekben nagyobb mennyiségben megtalálható a Dactylis glomerata, Poa angustifolia, Alopecurus pratensis. A fásszárú növények változatossága és azok valamelyik része táplálékforrást jelent a császármadárnak. Ezen fás szárú növények elegyfajként vannak jelen a biotópban. Ilyen a Betula pendula, Prunus padus, Carpinus betulus, Populus tremula, Alnus glutinosa, Salix cinerea Salix caprea, Sorbus aucaparia, és a Malus sylvestris. Az út 
mentén a cserjeszintben a Crataegus monogyna, Corylus avellana, Sambucus nigra, Berberis vulgaris. Említést érdemel a Rubus fruticosus, Rubus idaeus, Juniperus communis és a Rosa canina.

További létfontosságú lágyszárú fajok a császármadár táplálkozásának szempontjából:

- Kéküstökü csormolya (Melampyrum nemorosum)

- Mezei csormolya (Melampyrum arvense)

- Árnyékvirág (Majanthemum bifolium)

- Csattogó szamóca (Fragaria viridis)

- Olocsán csillaghúr (Stellaria holostea)

- Erdei mdársóska (Oxalis acetosella)

- Közönséges moha (Polytrichum commune)

- Kutyabenge (Frangula alnus)

- Kereklevelü körtike (Pyrola rotundifolia)

- Kúszó boglárka (Ranunculus repens)

- Berki szellőrózsa (Anemone nemorosa)

- Egyvirágú gyöngyperje (Melica uniflora)

- $\quad$ Erdei here (Trifolium medium)

- Bükk sás (Carex pilosa)

- Málna (Rubus idaeus)

- Gyepü rózsa (Rosa canina)

- Fekete bodza (Sambucus nigra)

- Gyertyánfa (Carpinus betulus)

- Mézgás éger (Alnus glutinosa)

- $\quad$ Rekettye füz (Salix cinerea)

- Mogyoró (Corylus avellana)

- Bibircses kecskerágó (Euonymus verucosus)

- Húsos som (Cornus mas)

- Rezgő nyár (Populus tremula)

A gerincek közelében Vaccinium myrtillus és Vaccinium vitis-ideae található, a déli kitettségü oldalakon, a gerincek mentén pedig egy 40 év körüli lucfenyves (Picea abies) erdőtag található. Az északi oldalakon az egész gerinc hosszában Dryopteris filix-mas, Asperula odorata társulása található meg különböző kormegoszlásban a rudas korú faállománytól a 120 éves korú állományig.

A bemutatott mintaterületeket az új tulajdonosok 1999 után folyamatos erdőkitermelési munkálatokkal érintették. Az I-es mintaterületen belül kevésbé és nem a megfigyelt biotópokon területén történtek a nagy erdőkitermelések, ezzel szembe a II-es mintaterület mindhárom kutatott biotópját folyamatosan zaklatták, minek következtében a korábbi állományszerkezet egyértelmüen megváltozott és az addigi ideális élőhelyi adottságok leszükültek.

Mindezek ellenére elmondható, hogy tavasszal az élőhelyi diverzitás növekedése jellemzi, míg ősszel az elszegényedés időszaka következik be. Az élőhely szerkezetének és minőségének tavaszi javulása a klimatikus viszonyok javulásával is együtt járhat, ami viszont nem törvényszerü és ilyenkor a predátorok közül is nagyon kevés van jelen, inkább a helyben szaporodók. Ezen időszak alatt a szaporodni készülö császármadarak számára a mintaterületeken belül megtalálható biotópokon a javuló feltételek időszaka következik be. Ezzel szemben az őszi időszakban az életfeltételek romlása törvényszerủen együtt jár a klimatikus viszonyok romlásával (hüvös, csapadékos ősszel) és a vonuló predátor fajok megjelenésével. 


\section{ANYAG ÉS MÓDSZER}

A császármadár populáció felmérését két mintaterületen végeztük. A két kiválasztott mintaterületen négyen végeztünk időszakos megfigyeléseket, felméréseket. A vizsgálatok 2001. augusztus eleje és december vége között, valamint 2002 márciusában és április első felében, illetve 2009. augusztus eleje és december vége közötti időszakban valamint 2010 márciusában és április első felében heti 1 észleléssel folytak, amelyek időpontja az adott hét szombatja vagy vasárnapja volt. A fő megfigyelő nap szombat, kedvezőtlen időjárás esetén a tartalék nap vasárnap volt. A vizuális meghatározáshoz 7×50-es távcsőt használtunk. A felnőtt (adult) madarak ivari elkülönítése megfigyelések alapján történt, föleg a tollazat alapján, mozgó vagy felrepülő egyedeket megfigyelve. Megfigyeléseinket tehát a párba állás és telelés időszakában hajtottuk végre, amelyek eredményeit a terepi jegyzőkönyvbe és térképen rögzítettem a pontosabb pozíció és terület meghatározás érdekébe.

A 2001/2002-es felmérés során $1000 \times 1000$ és 100×100 m-es hálóval segítettem a pontosabb pozíció meghatározást, amíg 2009/2010-es felmérések esetében 1000×1000 m-es hálóval. A felmérések alapján megállapítottam az élőhely-típust és az ivari viszonyokat. A mintaterületeken a megfigyelések során feljegyeztük, hogy a megfigyelt egyedek milyen élőhelyeken tartózkodtak, ezek az adatok jelentették a faj élőhely használatát. A vadőri tevékenységeknek köszönhetően - azonosított fészekaljak szerint - a költés időszakára vonatkoztatva is sikerült meghatározni azon területeket ahol a császármadarak tartózkodtak a költés-csibenevelés ideje alatt.

A mintaterületek vegetációszerkezetének meghatározásával rendelkezésünkre állt a vizsgálat időszakának élőhely kínálata. Az élőhely preferencia/választás meghatározására az IVLEV-index (FARAGÓ, 1997) alkalmazását választottuk.

Külön értékeltük a Csíkszeredai Erdészeti Hivatal és a Csíkszépvizi Erdészeti Hivatal által kezelt erdőterületeket, mivel a kiválasztott két mintaterület itt található. Mivel nagy jelentőséggel bír az erdőhasználati munkálatok intenzitása, erről külön értékelést készítettünk.

Vizsgáltuk a legeltetés hatását és annak változását, valamint az építkezési munkálatok növekedését, felhasználva Csíkszereda Megyei Jogú Város Polgármesteri Hivatala és a Csíkcsicsói Polgármesteri Hivatal statisztikai nyilvántartásaiban szereplő adatokat.

\section{EREDMÉNYEK}

\subsection{A császármadár megfigyelések 2001-ben}

Az I-es számú mintaterïlet megfigyeléseiről térképet készítettem, amelyről világosan kitünt, hogy a madarak három lokalizált területen tartózkodtak a vizsgálatok ideje alatt. A megfigyelések sorrendje a következő volt:

2001.IV.21-én, az első területen egy császármadár tyúk a kövezett erdei úttól 250 m-re a cserjeszintbe keresett menedéket a földön. Ez történt 9:30-kor. Több várakozás és síppal való csalogatás után sem jelent meg újra.

2001.IV.21-én a második területen a felhagyott földútról a fiatalosban keresett menedéket egy császármadár kakas, 11:17-kor. A hívósíp hangjára reagált a kakas, hallatta hangját kb. 20 percen keresztül, majd több várakozás után a síp hangjára egy másik kakas válaszolt a terület északkeleti irányából. A kakast nem láttam, a cserjeszint takarásában tartózkodott mindvégig.

2001.IV.21-én délután 17:25-kor a második területen a foglalt kút szomszédságában megpillantottam egy császármadár kakast. Rögtön az út menti takarást nyújtó cserjeszintben keresett menedéket. 
2001.IV.21-én délután 18:45-kor a harmadik területen a fiatalosba repült egy császármadár. A hívó hangjára válaszolt pár percen keresztül.

2001.V.5-én reggel 7:25-kor az egyes biotópon belül császármadár kakast figyeltem meg a terület nyugati peremén az egyik kis tisztás szélén. Amint észrevett hirtelen a cserjeszintben keresett menedéket a földön. Elkezdtem fészek után kutatni, de nem találtam.

2001.V.5-én a második területen hiába várakoztam-figyeltem, semmit sem észleltem.

2001.V.5-én, a harmadik területen nehézkes röptével egy tyúk a korona szintben keresett menedéket 13:45-kor.

2001.V.5-én 14:20-kor császármadár kakast pillantottam meg az április 21-én észlelt terület szomszédságában. Hiába keresgéltem fészek után kutatva, nem találtam semmit.

2001.V.19-én 8:00-kor az első területen egy megriadt császármadár kakas az idős állomány irányába nehézkes repüléssel menekült el. Hosszas várakozás után sem történt semmi, fészket továbbra sem találtam ezen a területen.

2001.V.19-én, 11:20-kor a második területen a felhagyott földúton császármadár tyúkot figyeltem meg. Porfürdőzött, azonban vedlett tollat nem találtam. Miután meg pillantott a földön távozva a cserjeszintben keresett menedéket. Fészket itt se találtam.

2001.V.19-én, 14:17-kor a harmadik területen a vizenyős terület szomszédságában levő sürü fiatalos elegyes területén császármadár tyúkot pillantottam meg. Sokáig mozdulatlanul várakoztam. Végül 14:25 - kor egy kakast láttam. Keresgélés után egy kidúlt rönk szomszédságában a sürün benőtt területen fészket találtam. 5 tojás volt a fészekben.

2001.VII.8-án, az első területen nem láttam semmit. A legeltetés viszont folyamatosan zajlott továbbra is a szomszédos területeken.

2001.VII.8-án a második területen, egy kis tisztáson napfürdőzött a császármadár kakas 9:45-kor. Megjelenésemkor hirtelen elmenekült. Fészket továbbra sem találtam.

2001.VII.8-án, a harmadik területen a fészek szomszédságában több időt töltöttem várakozással. Azonban nem történt semmi. A fészek üres volt, elhagyatottnak tünt. Feldúlás nyomait nem észleltem. Valószínünek tünt, hogy a kikelt fiókák már elhagyták a fészket. Némi várakozás után 18:15-kor hirtelen császármadár nehézkes röptének zajára lettem figyelmes. A zaj az idős állomány irányából hallatszott.

2001.VIII.19-én, az első területen semmit nem észleltem. A legeltetés már az erdő szélében is folyt. A nyájat őrző kutyák az erdő mélyebben fekvő területeire is bemerészkedtek.

2001.VIII.19-én 10:15-kor a foglalt kút szomszédságába cserregö hangadás után hamarosan felröppent egy császármadár. A kút melletti állományban keresett menedéket.

2001.VIII.19-én 17 és 18 óra között a harmadik területen a megszokott helyen egy császármadár tyúkot figyeltem meg pár másodpercig. Hiába várakoztam, a csibéket nem láttam.

2001.X.7-én 9:00-kor az első területen továbbra sem tapasztaltam semmit, ami a madarak jelenlétére utalna. Egy másik dolog keltette fel a figyelmemet a rengeteg kiránduló túrázó.

2001.X.7-én, 12:10-kor a második területen a foglalt kút szomszédságában síppal próbáltam hívni a császármadár kakast. A síp hívóhangjára egy nyuszt merészkedett elő. Amint megpillantott mereven figyelt pár másodpercig, majd fürge mozdulatokkal eltünt az avarba. A síppal való hívást tovább folytattam, minek az lett az eredménye, hogy a kakas megint válaszolt. Nem zavarta meg nyuszt jelenléte, inkább a territoriális védelem érdekelte. Hangos nehézkes röptével közeledett felém. Nem láttam a még lombozattal rendelkező fák jó takarása miatt.

2001.X.7-én 15-16 óra között a harmadik területen a hívó sípra egy magányosnak tủnő kakas válaszolt. Mindez a megszokott hely közelében történt, a vizenyős területet sürün borított cserjés fiatalos szomszédságában. Rövid időn belül elindultam a kakas irányába, de gyors szárnycsapásokkal elhúzott az idős állományon belül.

Az ösz folyamán még egyszer jártam kint a területen, felkerestem az eddigi megfigyelési helyeket, de eredménytelenül.

A II-es számú mintaterületen elvégzett vizsgálatokból kitünik, hogy a madarak ugyancsak három biotópon belül tartózkodtak. Az elvégzett megfigyelések sorrendje és a császármadarak térbeli mozgása a következő volt: 
2001.IV.22-én reggel 7:00-kor egy császármadár kakas közvetlenül a kövezett erdei autóútról repült fel, párhuzamosan az úttal repülve a cserjeszintbe szállt be. Az úton tovább haladva a második terület irányába, a földről a mogyoró bokrok alól egy császármadár kakas az állományalkotó erdő felé repült.

2001.IV.22-én 14:05-kor a második területen szintén az út melletti csalános-málnás területekről egy tyúk elöször egy közeli fa ágára repült, majd a patak irányába nehézkes szárnycsapásokkal elrepült. A második területen többet nem észleletem ezen a napon.

2001.IV.22-én 17:10-kor a harmadik területen egy császármadár zajos röpte volt hallható. Sípszóra nem válaszolt.

2001.V.6-án reggel 7:10-kor az első területen az útnak egy napsütötte foltjáról repült fel egy madár.

2001.V.6-án reggel 7:20-kor az út menti cserjeszintből repült ki egy madár.

2001.V.6-án 9:30-kor a második területen az út mentén található aljnövényzetből egy császármadár kakas szállt fel és repült el a patak irányába. Síppal történő hívásomra a madarak ezúttal se válaszoltak.

2001.V.6-án 14:20-kor a harmadik területen a tisztásról az erdőbe érve császármadár tyúkot pillantottam meg. Sokáig mozdulatlanul várakoztam, majd síppal kezdtem hívni a madarakat, eredménytelenül.

2001.V.6-án visszatértem a második területre. 16:10-kor császármadár tyúkot pillantottam meg amint a vizenyős terület melletti sürüben keresett menedéket a földön futva. Több idős keresgélés után fészket találtam az erdei autóúttól a patak irányába vezető ösvény mellett, egy erdei iszalaggal eléggé sủrün befutott bokor mellett a földön. A fészekben három tojás volt. Hiába várakoztam néhány méterrel odébb, nem történt semmi.

2001.V.20-án reggel 6:30-kor az első területen porfürdőző császármadár kakast pillantottam meg. A földön szaladva az út menti cserjés alatt keresett menedéket. A porfürdőzés alkalmával vedlett tollat nem találtam.

2001.V.20-án, 9:25-kor a második területen lévő fészekhez siettem. A fészket üresen találtam. A területen sok kirándulóval találkoztam. A közeli nyílt területen hétvégi házakat építettek.

2001.V.20-án 11:45-kor a harmadik területen császármadár kakast pillantottam meg amint a tisztásról az erdő irányába repült. Hosszabb idejü várakozás után se láttam madarat.

2001.VII.3-án 7:15-kor az első területen hiába jártam nem találkoztam egy madárral sem.

2001.VII.3-án 11:30-kor nehézkes burrogó röptet hallottam a vizsgált terület irányából. Madarat, egyet se láttam.

2001.VIII.4-én az első és második területeket jártam végig, egy madarat sem találtam. Sok kiránduló emberrel találkoztam.

2001.VIII.4-én 9:50-kor a harmadik területen a tisztás közvetlen közelében egy császármadár tyúk felrepült a fiatal páfrányos-bükkös irányába. Ezek után két csirkét pillantottam meg, amint a bükkös irányába szaladtak.

2001.VIII.23-án reggel 8:00-kor az első területen egy madarat se láttam.

2001.VIII.23-án délelőtt 10:10-kor a második területen ugyanaz a helyzet.

2001.VIII.23-án délután 14:25-kor egy császármadár kakas a korona szint alatt található fiatalosba szállt a tisztás irányából.

2001.IX.9-én, a harmadik területen 11:25-kor figyeltem meg egy császármadár tyúkot az erdő szélétől úgy kb. 20 m-re kelet irányában a tisztáson található mogyoróbokrok alatt. Miután észrevett egy 10-15 m-es futás után felrepült és szintén a páfrányos-fiatal bükkösben keresett menedéket.

2001.X.14-én bejártam az első és második területet, egy madarat se láttam.

2001.X.14-én 11:20-kor a harmadik területen síppal próbáltam becsalni a császármadár kakast. Itt is egy nyusztot pillantottam meg, amely azonban nagyon gyorsan eltünt.

2001.X.20-án 12:10-kor síppal hívtam a madarakat. Nem válaszolt egy madár sem.

2001.X.20-án 17:45-kor folytattam a síppal történő hívást, melyre válaszolt a madár pár percig.

2001.X.21-én 7:40-kor a harmadik területen síppal hívtam a madarakat. Nem válaszolt egy madár sem.

Az ősz folyamán még két alakalommal bejártam a II-es mintaterület biotópjait. Az addig megfigyelt három területen egy madarat sem láttam. 


\subsection{A császármadár megfigyelések 2002-ben}

Az I-es számú mintaterületen végzett megfigyelés időrendben az alábbiak voltak:

2002. III. 9-én jártam először a területen. Kimondottan a déli kitettségủ helyeken kutattam a madarak után. Nagy meglepetésemre az I-es mintaterület első biotópjának Bilibók pusztája felőli cserjével borított erdőszéli területén kisebb-nagyobb kupacokban egymástól pár lépésnyi távolságra császármadár ürülék halmokat találtam. Nagy volt a valószínüsége annak, hogy a madarak a téli időszak egy részét ezen a területen töltötték. A zavaró tényezők hatására erről a helyröl 2001-ben eltüntek, majd valószínüleg a zavarás megszünése után visszamerészkedtek erre a területre. Ugyanezen a napon a második és harmadik területeket is bejártam. A második területen nem találtam semmit. A harmadik területen, a forrás környékén még mindig nagy volt a hó. Semmi nyomot nem találtam. Feljebb haladva a fiatal nyíres-mogyorós, égeres területen az első biotóphoz hasonlóan az elolvadt hó foltokon császármadár ürülék kupacokat találtam, ami telelésre utal. A legtöbb áttelelésre utaló nyomot az első területen találtam.

2002.III.30-án 9:30-kor az első területen burrogó zajos repülő császármadarat halottam. A madarat nem sikerült megfigyelnem.

2002.III.30-án 12:45-kor a második területen síppal próbáltam a madarakat hívni. Próbálkozásom sikertelen volt. Se nyomot se ürüléket nem találtam.

2002.III.30-án 14:15-kor egy-két napos ürüléket találtam a hármas területen. Az ürülék a vizenyős terület szomszédságában található sürü cserjés szélében volt. Ebből mintát is vettem a későbbiek kiértékelése céljából. Madarat nem láttam és nem is hallottam.

2002.IV.7-én reggel 7:30-kor császármadár kakast pillantottam meg az első terület egyik kis tisztásának szélén. Nehézkesen elrepült az idős fenyves állomány irányába, a koronaszint magasságában.

2002.IV.7-én 7:45-kor szintén az első területen egy másik kis tisztáson császármadár tyúkot vettem észre. Rövid időn belül a földön szaladva távozott a tisztás mentén található alacsony cserjeszintbe.

2002.IV.7-én 11 és 12 óra között a második területen síppal hívtam a madarakat a foglalt kút szomszédságában. A hívás nem volt eredménytelen, rövid időn belül egy császármadár kakas hallatta hangját, majd tőlem északkelet irányban egy másik is megszólalt.

2002.IV.7-én 12:20-kor az északkeleti völgy irányából a kakas már egészen közel merészkedett. Rövid időn belül hallottam, hogy észak irányba elrepült.

2002.IV.7-én 15 és 16 óra között a harmadik terület vizenyős részének közelében próbáltam síppal hívni a madarakat. Többször próbálkoztam mire egy választ kaptam a gyertyános-nyíres irányából. Madarat nem sikerült megfigyelnem.

2002.IV.7-én 16:30-kor a március 30-án talált ürüléktől kis távolságra császármadár tyúkot figyeltem meg. A föld felszínéről szedegetett. Pár perc után a földön futva távozott a sürü borítású cserjeszint alá.

2002.IV.28-án 7 és 8 óra között az első területen egy császármadár kakast pillantottam meg az idős állomány alatti újulatban. Nem vett észre. Amint meg tudtam figyelni felemelt farokkal, gyors léptekkel a cserjeszint alá menekült.

2002.IV.28-án 10:18-kor a második területen a felhagyott földúttól kb. $5 \mathrm{~m}$-re figyeltem meg egy császármadár tyúkot. Az elején lassan járt, majd feltartott farokkal, gyors léptekkel távozott a kúttól északi irányban.

2002.IV.28-án 12 és 13 óra között az úton haladva a harmadik terület irányába egy császármadár kb. 5-6 m-t futott az úton elöttünk, majd szárnyra kapott, repült 25-30 m-t, majd a völgy irányába távozott a földön futva.

2002.IV.28-án 15 és 16 óra között császármadár kakas szállt fel a harmadik terület egy kis tisztásáról. Mozdulatlanul követtem egy nagy fa mellől. Pár percnyi várakozás után a vizenyős terület felé haladva kb. 10-15 m-re újból láttam a madarat.

2002.V.23-án reggel az első terület szomszédságában birka sereg legelészett. A seregre felügyelő kutyák mélyen bemerészkedtek az erdőbe. Ezen a területen egy madarat se sikerült megfigyelnem a hosszú várakozás ellenére sem. 
2002.V.23-án 11:10-kor a foglalt kút környékén egy császármadár tyúk az út széléről repült fel, az idős állomány fölött északkelet irányába repült. A megfigyelések függvényében a környéken fészeknek kell lennie.

2002.V.23-án 14-15 óra között egy kidőlt fa törzse mellett, a foglalt kúttól északkeleti irányban a vízmosás közvetlen szomszédságában a cserjeszint alatt a földön császármadár fészket találtam, benne 3 tojással.

2001.V.23-án 17:00-kor a harmadik területen a vizenyős terület irányából császármadárra utaló cserregö, riasztó hangot hallottam. Madarat ekkor sem láttam.

2002.V.30-án felkerestem az első területet. A legeltetés folyamatosan zajlott tovább, ezért itt nem láttam császármadarat. Tovább haladva a második területre az ott megtalált fészket feldúlva találtam. Pontosan nem tudtam megállapítani, hogy vaddisznó vagy esetleg más ragadozó okozta a fészek pusztulását.

2002.VII.7-én 11:00-kor a harmadik területen kutattam császármadár után. Fészket nem találtam, de kb. 25 m-re előttem kakas és tyúk egymás mellett párhuzamosan repült felfelé az idős fenyőállomány irányába. A madarakat nem sikerült újra megfigyelnem.

2002.VII.7-én 16 és 17 óra között a második területen próbáltam a madarak után kutatni. Egy császármadár tyúkot sikerült megfigyelnem amint a bokrok között kapirgált, a feldúlt fészek irányában. Hamar észrevett, repülés közben irányt változtatott és eltủnt az út fölötti fiatalosban.

2002.VIII.17. Az első területen nem észleltem semmit, a legeltetés folyamatos volt.

2002.VIII.17. A második területen a foglalt kútnál legelö állatokat itattak.

2002.VIII.17. A harmadik területen a késő esti órákig várakoztam. Egyetlen madarat sem sikerült megfigyelni.

A II-es számú mintaterületen valamivel hamarabb kezdtem el a vizsgálatokat a jobb terepi viszonyok miatt. Így

2002.II.23-án próbautat végeztem. A nagy hó miatt azonban csak az első és a második területnek az úttal szomszédos részeit kutattam át. Az első területen nem találtam semmit. A második területen egy mogyoróbokor alatt közel a patakhoz, barka darabokat és mellettük császármadár hullatékot találtam. A környéken farkas nyomokat is láttam. A fentiek függvényében a császármadarak újból megjelentek a második biotóp területén.

2002.III.24-én felkerestem a harmadik területet, de nem találtam semmit. A második területen a patak menti égerfák és kecskefüzek alatt, füzbarka darabokat és 26 rakás hullaték csomót találtam. Ezek nem voltak frissek, a tél folyamán itt töltött jelenlétükről tanúskodtak. Az első terület közvetlen szomszédságában található mogyoróbokros nyílt terepen a hó már csak nagyobb foltokban volt jelen. A megjelent füves terepen a mogyoró bokrok között több császármadár hullatékot észleltem. A hullatékok nem voltak frissek, valószínü, hogy a téli időszak egy részét töltötték ezen a területen. A területtől nem messze található gyertyán volt a téli gallyazó helyük.

2002.III.31-én a második területen a kecskefüzek alatt friss császármadár ürüléket találtam.

2002.IV.14-én reggel 8 és 9 óra között az első területtől délkeletre eső bozótos területen figyeltem meg egy tyúkot és egy kakast. Amint észrevettek az úton átrepülve a bokros erdőbe menekültek.

2002.IV.14-én 11:20-kor a második területen áthaladó út kanyarjában észleltem egy tyúkot. A madár riasztó hangot hallatott és felrepült az út melletti idős fenyő állomány korona szintjébe.

2002.IV.14-én, a hármas területen nem észleltem semmit.

2002.IV.21-én 8 óra után az első területen síppal hívtam a madarakat. Az idős állomány és az út között elterülő cserjés irányából válaszolt a kakas.

2002.IV.21-én 12:10 körül a második területen haladva egy császármadár kakas a földről az idős állomány korona szintjébe repült. Kis várakozás után, visszarepült az út menti cserjeszint alá.

2002.IV.21-én 17 óra után hívó sípolásomra válaszolt a császármadár kakas, de sajnos nem láttam.

2002.V.28-án 13:30-kor az első terület szomszédságában zajos építkezést folytattak, emiatt egy madarat sem sikerült megfigyelnem.

2002.V.28-án 15 óra után a második területen nagy meglepetésemre császármadár tyúk porfürdőzött. Amint meglátott rögtön a földön futva keresett menedéket. A porfürdőzés helyén tollat nem találtam. 
Meglepett az a tény, hogy az építkezésekhez a vizet erről a területről szállították és mégis tartózkodott császármadár a környéken. Rögtön fészek után kezdtem kutatni, de nem találtam. Szintén ezen a napon az elegyes állomány irányából cserregő hangadás után, közvetlenül burrogó repülést hallottam. Beigazolódott, hogy az antropogén zavaró tényezők ellenére még mindig volt madár ezen a területen.

2002.V.29-én délután 16:30-kor a harmadik területen a tisztás széli cserjeszint irányából hallottam a császármadár riasztó hangját. Pillanatokon belül nehézkes röptével távozott. Meggyőződtem, hogy most már biztos a madár jelenléte a környéken.

2002.VI.2-án 16 óra után a harmadik területen tovább kutattam fészek után. A 15-20 éves fiatal bükkös és cserjeszint között, a sủrü aljnövényzetben a földön fészket találtam 5 darab tojással.

2002.VI.9-én reggel a harmadik területen található fészekhez siettem. A fészek üres volt, el volt pusztítva. Az ok számomra ismeretlen maradt. Rövid ideig még a területen tartózkodtam, de nem tudtam semmit megfigyelni, madár nem jelentkezett.

2002.VII.14-én végigjártam a területeket. Madarat nem észleltem se az első se a második területen.

2002.VII.14-én 15:20-kor a harmadik területen a tisztás széli málnásban fel-felugráló tyúkot pillantottam meg. Amint észrevett rögtön távozott a földön. További várakozásom eredménytelen maradt.

2002.VIII.19-én 14-kor a tisztás szélén található köves-hangyabolyos területen egy tyúkot és egy kakast figyeltem meg. Bogarásztak és amint észrevettek, a délkeleti kitettségü idős állomány koronaszintjébe menekültek.

2002.IX.15-én 11:30-kor a harmadik területen a tisztás mentén jobb oldalt felfelé haladva egy kakast láttam kb. 50 m-es távolságra előttem. Az idős állományból repült az északkeleti kitettségü idős állomány irányába.

2002.IX.29-én végigjártam még egyszer a területeket. A vizsgálatot sípolással kezdtem mindjárt a reggeli órákban. Az első helyen időközben megnőtt a gombászók és kirándulók száma. Madarat viszont továbbra sem láttam és nem is hallottam. A második területre erdő kitermelő munkások érkeztek. Fölöslegesnek találtam a vizsgálatokat tovább folytatni.

\subsection{Császármadár megfigyelések 2009-ben}

A 2009-es év folyamán a vizsgálatokat és megfigyeléseket a korábban kijelölt két mintaterületen belül végeztem, el három hívatásos vadász segítségével.

Az I.- es számú mintaterület jelenlegi megfigyelései alapján kiderült, hogy a madarak a korábbi három lokalizált területről mára csak két területen belül tartózkodtak a vizsgálatok ideje alatt.

Az I.- es mintaterïleten végzett megfigyelések sorrendje:

2009.VIII.1-én, az első területen nem láttunk semmit.

2009.VIII.1-én a második területen nem azonosítottunk semmit.

2009.VIII.1-én, a harmadik területen a fiatalos szélébe az egyik vadőr azonosított egy császármadarat délelőtt 9:25-kor. Több várakozás után se történt semmi.

2009.VIII.1-én, a harmadik területen 17:45-kor szintén a fiatalosba azonosított a vadőr ez alkalommal két császármadarat. Amint észrevették a vadőrt, a cserjeszintbe kerestek menedéket a földön.

2009.VIII.8-án, az első területen nem sikerült azonosítani császármadarat a délelőtt folyamán. A délutáni megfigyelések szintén eredménytelenül zajlottak le.

2009.VIII.8-án a második területen belül reggel 8:15-kor egy császármadár kakast figyelt meg a vadőr. Hírtelen a cserjeszintbe tünt el, menedéket keresve a földön.

2009.VIII.8-án az esti órákban 19:45-kor egy császármadár tyúkot azonosított a vadőr szintén a cserjeszinten belül. A megfigyelés a második területen történt.

2009.VIII.8-án, a harmadik területen két császármadarat azonosítottak a hívatásos vadászok. Az egyik madár reggel 7:10-kor a korona szintbe keresett menedéket, míg a másik délután 16:45-kor, a cserjeszintbe keresett menedéket. A nap hátra levő részében nem észleltek semmi mást. 
2009.VIII.15-én, az első területen nem észleltünk semmit. A legeltetés folyamatosan zajlott a megfigyelt területen belül és annak szomszédságában. A közeli erdörészekben terepmotorosok tartózkodtak.

2009.VIII.15-én a második területen megriadt császármadár kakast észleltem, nehézkesen a korona szintbe keresett menedéket. Mindez reggel 8:00-kor történt. A nap hátra levő részében nem történt semmi a területen belül.

2009.VIII.15-én, a harmadik területen a vadör egész nap nem észlelt semmit.

2009.VIII.22-én az első terület közvetlen szomszédságában tovább folytatódtak az erdőhasználati tevékenységek. A nap folyamán császármadarat ezen a területen nem figyeltünk meg.

2009.VIII.22-én a második területen a földút szomszédságában császármadár kakast azonosított a vadőr. A madár a fiatalosba keresett menedéket. Mindez 9:10-kor történt. A császármadár a fiatalosba tartózkodott mindvégig.

2009.VIII.22-én a régi kút szomszédságában nem messze a délelőtti megfigyelési területtől egy másik császármadarat figyeltünk meg. A madár ezúton a közeli cserje szintbe menekült. A megfigyelés 17:45-kor történt. A császármadár nagyon sokáig mozdulatlan volt, majd hírtelen a földön elmenekült.

2009.VIII.22-én, a harmadik területen csak délelőtt végeztünk megfigyeléseket. 7:20-kor nehézkes röptével egy császármadár tyúkot azonosított a vadőr a korona szintjébe. A madár némi várakozás után a földre szállt, majd a közeli cserjeszintbe keresett további menedéket.

2009.VIII.22-én szintén a harmadik területen 11:20-kor egészen fiatal császármadarat figyelt meg a vadör. Ezúton a madár a földön tartózkodott a biotóp szélén található tisztáson. Amint észrevette a vadört a cserjeszintbe keresett menedéket. Ezúton megint terepmotorosok randalíroztak a környéken.

2009.VIII.29-én, az első területen a reggeli és délelötti időszakba nem észleltünk semmit. A megfigyeléseket megismételtük a délutáni és az esti órákba is. Az eredmény ugyan az.

2009.VIII.29. A második területen $18^{25}$-kor a foglalt kút szomszédságában császármadár kakast figyeltem meg. Az út menti cserjeszintbe keresett menedéket.

2009.VIII.29-én reggel $8^{15}$-kor a harmadik területen egy vizenyős terület szomszédságában levő sűrüfiatalos elegyes területén császármadár tyúkot azonosított a vadőr.

2009.VIII.29-én 15-16 óra között ugyan ezen a területen császármadár kakast figyeltünk meg. A kakas rövid várakozás után a korona szint magasságába az idős állományon belül keresett menedéket.

2009.IX.5-én, az első területen erdőhasználati tevékenységek folytak. Császármadarat nem figyeltünk meg a területen.

2009.IX.5-én a második területen 9:00-kor a foglalt kút szomszédságában felröppent egy császármadár. A kút melletti állományba keresett menedéket. Az elkövetkezendőkbe nem észleltünk más császármadarat.

2009.IX.5-én délután 17:45 körül a régi út szomszédságában található csalános-málnásból egy tyúk először egy közeli fa ágára repült, majd a patak irányába nehézkes szárnycsapásokkal elrepült. A továbbiakban a területen levő vadőr nem tapasztalt semmit.

2009.IX.5-én, a harmadik területen reggel 7:30-kor a területen tartózkodó hivatásos vadász császármadarat figyelt meg amint a tisztásról az erdő irányába repült. Hosszabb várakozás után az adott területen nem látott császármadarat a szakember.

2009.IX.5-én 18 és 19 óra között a harmadik területen császármadár tyúkot azonosított a vadőr. A madár az erdő szélétől úgy kb. 25-30 m-re a közeli tisztáson található mogyoró bokrok alatt tartózkodott. Rövid idő után felrepült és a páfrányos-fiatal bükkös irányába keresett menedéket.

2009.IX.18-án, az első területen erdőhasználati munkálatok folytak. A szomszédos területeken birkanyáj legelt. A nyájat őrző kutyák mélyen behatoltak az erdőbe. Császármadarat nem láttunk. Ezen a napon további megfigyeléseket nem végeztünk ezen a biotópon belül.

2009.IX18-án a második területen belül a kút szomszédságában 12 óra körül császármadarat figyeltünk meg. A kút szomszédságában található állományba keresett menedéket.

2009.IX.18-án a kora délutáni órákba a régi út mentén található alj növényzetből két császármadarat láttunk felrepülni. A madarak a fiatal bükkös felé repültek. Tovább várakoztunk, de madarat többé nem láttunk.

2009.IX.18-án az esti órákba 19:45-kor a harmadik területen a hívatásos vadász császármadár kakast látott a patakmeder szomszédságában. A madár a közeli égeresbe keresett menedéket. A továbbiakban 
még egy császármadarat látott és azonosított a vadőr valamivel távolabb szintén az égeresbe. Ezúton egy császármadár tyúkot figyelt meg.

2009.IX.26-án, az első területen nem végeztünk megfigyeléseket. Fölöslegesnek találtam, mivel a közelben nemcsak erdőhasználati tevékenységek folytak, hanem építkezések is.

2009.IX.26-án a második területen egész napos megfigyeléseket végeztünk. A tevékenységet végzö személyek három különböző területen tartózkodtak és a következő adatokat szolgáltatták:

- a foglalt kút szomszédságában két császármadarat látott a vadőr. A későbbiekben egy tyúkot és egy császármadár kakast azonosított a szomszédos cserje szint alatt. A figyelmes madarak a sủrü málnásba kerestek menedéket. A továbbiakban a madarakat többé nem látta a vadör.

- a Bilibók puszta szomszédságában található fiatal bükkösben császármadár kakast figyeltem meg a délelőtti órákban. A kakas rövid tartózkodás után a közeli cserjeszintbe e menedéket a földön. Délután 14:30 és 16 óra között további két madarat láttam a távolabbi tisztáson. A madarak hamar észrevettek és nehézkes repüléssel a bükkös irányába távoztak. Az esti órákig több madarat nem észleltem.

- A felhagyott erdei út szomszédságában a másik vadör végzett megfigyeléseket. Reggel 8:30-kor napfürdőző császármadarat azonosított. A madár a közeli elegyes állományba keresett menedéket amint észrevette. Délután 14:45-kor másik két császármadarat azonosított. A madarak rövid ideig voltak megfigyelhetők, szintén az elegyes állományba kerestek menedéket a földön távozva. Az esti órákba még egy császármadár tyúkot sikerült azonosítani ezúton a közeli cserjeszint takarásába. A madár elég hosszasan időzött a sürü málnás-szedres cserjeszintbe.

2009.IX.26-án, a harmadik területen a forrásvidék szomszédságában egy császármadár kakast azonosított a harmadik vadőr. A madár keveset tartózkodott a területen, miután észrevette a vadőrt a szomszédos állományba keresett menedéket a földön távozva. A délutáni órákba szintén ezen a területen egy császármadár tyúkot azonosított. Ez a madár valamivel hosszabb ideig tartózkodott az adott területen majd nyugodt léptekkel távozott a cserjeszintbe.

2009.X.10-én a délelőtti órákba az első területen nem tapasztaltunk semmit. Kirándulok lepték el a környéket.

2009.X.10-én a második területen 11:30-kor a foglalt kút közvetlen szomszédságában hívtuk a császármadár kakasokat. Nem válaszolt semmi.

2009.X.10-én szintén a második területen a patakhoz közeli égeresbe próbálkoztunk hívással. 14:30 tájékán nehézkes röptével halottuk a császármadár kakas közeledtét. Látni nem láttam, mert hírtelen távozott amint megpillantott minket a közeli cserjeszintben. Ezen a napon több madarat nem láttunk.

2009.X.10-én a harmadik területhez közeli erdőtagban erdőhasználati munkálatokat folytattak. Ennek következtében megfigyeléseket itt nem folytattunk.

2009.X.18-án a második területen a patakhoz közeli égeresbe próbálkoztam hívással. A hívásra nem válaszolt semmi.

2009.X.18-án a foglalt kút mellett 10 óra körül megint próbáltam hívni a császármadarakat. Ezen úton sikerrel, mert látni véltem a közeledő kakast. Hamarosan észrevett és távozott határozott magatartással, a közeli cserjeszintbe a földön. Ezen a napon a második területen több madarat nem azonosítottunk.

2009.X.18-án, a harmadik területen császármadár párt azonosított az ott tartózkodó vadőr. A madarak a vizenyős terület melletti cserjeszintbe tartózkodtak elég hosszú időn át. 11 óra után nehézkes repüléssel távoztak a közeli bükkösbe.

2009.X.18-án a délutáni órákba egy fiatal császármadár kakast azonosított a hívatásos vadász szintén a harmadik területen. A megfigyelés ezúton a patak melletti égeresbe történt. A madár hosszasan tartózkodott ezen a területen. A földön távozott az égeres után következö cserjeszintbe.

2009.X.24-én megfigyeléseket csak a második és harmadik területen végeztünk. A második területen 10:45-kor császármadár párt azonosítottunk a foglalt kút melletti cserjeszintbe. A madarak nagyon figyelmesek voltak és kevés idő után a közeli korona szintbe repültek. Ezen a napon a második területen több madarat nem láttunk.

2009.X.24-én, a harmadik területen a vadőr a fiatal bükkös szomszédságában 12:20 és 14 óra között egy pár császármadarat figyelt meg amint a földön a tisztás melletti cserjeszint irányába távoztak. A cserjeszintböl többször kiváltottak a tisztásra majd újból vissza. Végül az égeres irányába távoztak repülve. 
2009.XI.7-én az első terület melletti erdőtagokba erdőhasználati tevékenységeket folytattak. Nem láttam értelmét megfigyelések folytatására. A továbbiakban kettős csoportokba folytattunk megfigyeléseket a kettes és hármas biotópokon belül. Császármadarat egész nap nem láttunk.

2009.XI.15-én az első terület közvetlen szomszédságában még mindég legeltek a birkák. A területen pásztorkutyák szaladgáltak keresztül-kasul. Értelmetlen volt a megfigyelések folytatása.

2009.XI.15-én még egyszer körbe jártuk a kettes és hármas területeket, de sajnos eredménytelenül.

2009.XI.28-án császármadarat nem láttunk. Elhatároztam tovább kutatunk a közeli területeken. A szomszédos vadásztársaság területeire áthatolva körbe jártuk a környéket eredménytelenül.

2009.XII.5-én a szomszédos vadásztársaság területén császármadár ürüléket találtunk. A megfigyeléseket tovább folytattuk minek köszönhetően az adott területen még több ürüléket sikerült azonosítani. A terület déli kitettségü, fiatal nyíres sok közönséges mogyoróval. Császármadarat viszont nem láttunk. A környéken sok volt a szabad állású idős bükkfa.

2009.XII.5-én délután átfésültük a harmadik biotópot császármadár jelenlétére utaló nyomokat keresve, eredménytelenül.

2009.XII.12-én az I.-es mintaterület 2-es biotópján hajtottunk végre megfigyeléseket. A korábban megfigyelt foglalt kút szomszédságában császármadár ürüléket találtunk a mézgás éger és a cserjeszint szomszédságában. További ürülékeket találtunk a felhagyott erdei úttól nem messzire található nyíres, gyertyános bükkös szomszédságában a közönséges mogyoró bokrok alatt. A területen újból megjelentek a császármadarak.

2009.XII12-én a harmadik területen található forrásvidéken friss császármadár ürüléket talált a vadőr. A területen a madarak jelenlétére utaló más nyomot nem sikerült azonosítani.

2009.XII.19-én a második biotópon a korábban megfigyelt területeken folytattunk megfigyeléseket. A foglalt kút környékén átkutatva a területet több kupac ürüléket találtunk. A kupacok között találtunk egészen friss ürülékeket is.

2009.XII.19-én a harmadik biotópon belül a kora délutáni órákban megkerestük a forrás környékét. Több ürüléket sikerült azonosítani, amiből arra következtettem, hogy ezen a területen is nagyobb számba jelentek meg a császármadarak. Sajnos madarat nem sikerült megfigyelni. Az I.-es mintaterületen 2010. március első feléig nem végeztünk megfigyeléseket.

A II.-es mintaterïleten végzett megfigyelések alkalmával felkerestük a korábban kijelölt három biotópot. A nagyméretü erdőhasznosítási tevékenységek következtében ez a müvelet nagyon nehéz volt, mert a területen folytatott munkálatok következtében teljesen megváltozott a környezetet.

2009.VIII.7-én felkerestük az első korábban kijelölt biotópot. Ez az élőhely nagyon megváltozott a folyamatos hasznosítások következtében. Jelen pillanatban nem folytattak semmilyen jellegü tevékenységet, viszont a szomszédos parcellákban folytak a hasznosítási munkálatok. Császármadár a területen nem létezett.

2009.VIII.7. A kettes területen erdőhasználati munkálatokat folytattak.

2009.VIII.7. A hármas területen erdőhasználati munkálatokat folytattak.

2009.VIII.14-én az első terület szomszédságában folytatódtak a hasznosítási munkálatok. A közeli tisztáson terepmotorosok gyakorlatoztak.

2009.VIII.14. A második területen folytatódtak a korábbi munkálatok. Az erdőhasznosítás kiterjedt a közeli beerdősödött kaszálóra is.

2009.VIII.14. A harmadik területen szintén folytak az erdőhasznosítási tevékenységek.

2009.VIII.23. Az első biotóphoz közeli területen építkezési munkálatokat folytattak. Rengeteg turista tartózkodott a környéken.

2009.VIII.23. A második és harmadik területen folytatódtak a korábban elkezdett munkálatok.

2009.IX.12-én az első területhez közel terepmotorosok gyakorlatoztak. Ezzel párhuzamosan folytatódtak az építkezési munkálatok a biotóphoz közeli területeken.

2009.IX.12-én a második és harmadik területen a korábban elkezdett erdőhasználati tevékenységek folytatódtak. Ezen a napon két vadőr társaságában elkezdtünk más császármadár biotópok után kutatni a korábban kiválasztott mintaterülettel szomszédos övezetekben. 
2009.IX.27. A korábban kijelölt három biotópon kívül tovább folytattuk a császármadarak utáni kutatásokat. Császármadarat nem találtunk.

2009.X.3-án az első terület szomszédságában befejeződtek a munkálatok.

2009.X.3. A második és harmadik területen folytatódtak a korábban elkezdett tevékenységek.

2009.X.3. Császármadarak után kutatva elérkeztünk a szomszédos vadásztársulat területére. Távol a kitermelési és hasznosítási tevékenységektől császármadárra utaló nyomokat találtunk. A környéken zavaró jellegü tevékenységeket nem folytattak.

2009.X.31-én befejeződtek a munkálatok a második és a harmadik területen is. A közeli erdei úton aznap terep autóversenyt rendeztek. Hatalmas tömeg érkezett a környékre. Teljes a hangzavar, nagy a mozgás, járkálás a területen.

2009.X.31-én, az első területen a fentiek függvényébe nem észleltünk semmit.

2009.XI.6-án egész napos megfigyeléseket tartottunk. 8:45-10:30 között az első területen nem észleltünk semmit. Időszakosan megjelent legelő juhok és rohangáló pásztorkutyák tartózkodtak a napnak ezen időszakában a területen. A második és harmadik területen császármadarat nem észleltünk. A délutáni órákban a szomszédos területeken kerestük a madarakat. Nem észleltünk semmit.

2009.XI.20-án a korábbi biotópoktól távolabbra eső területeken 10:20-kor császármadár kakast figyeltünk meg. A kakas a korona szint alatt található fiatalosba szállt a tisztás irányából. Valamivel később egy császármadár tyúkot vettünk észre. Az erdő szélétől nem messze kb. 20-25 m-re a tisztáson tartózkodott a mogyoró bokrok alatt. Miután észrevett a földön távozott majd felrepülve szintén a fiatalosba szállt. Nagy örömünkre megjelentek a császármadarak a környéken.

2009.XII.4-én, az első területen nem észleltünk semmit.

2009.XII.4-én, második-harmadik területen nem észleltünk semmit.

2009.XII.4-én a korábban észlelt császármadarak után kutattunk. Dél-nyugatra az eredeti mintaterülettől a szomszédos vadásztársulat határában császármadár ürülékeket találtunk. Az ürülék többnaposnak bizonyultak. Császármadarat ezen a napon nem láttunk.

2009.XII.13-án körbe jártuk a mintaterület három biotópját. Császármadarat a környéken nem figyeltünk meg. A nap hátralevő ideje alatt felkerestük azokat a helyeket ahol korábban ürülékeket találtunk. 12:20-kor teljesen friss császármadár ürüléket fedeztünk fel egy kisebb tisztás közvetlen közelébe. Alaposan körbejárva a környéket még több ürüléket találtunk.

2009.XII.13-án a késő délutáni órákba további ürülék kupacokat fedeztünk fel a bükkös szélétől nem messzire húzódó égeres, mogyorós területen. Hosszabb várakozás után se láttunk madarat.

2009.XII.18-án a frissen hullott hóban felkerestük a korábbi három biotópot. Császármadarak jelenlétére utaló nyomokat nem találtunk egyik területen se.

2009.XII.18-án a korábban kiválasztott mintaterülettől nem messzire dél-nyugat irányában ürülék kupacokat találtunk az égeres-mogyorós borítottságú területeken. A környéken nagy volt a csend. A mintaterület szomszédságában most már biztosan megjelentek a császármadarak. Az ürülékek valamint az éger és mogyoróbarka darabok jelenlétüket igazolja. Ezen a mintaterületen 2010. február végéig nem végeztünk további megfigyeléseket a nagy hó, valamint a nehéz út viszonyok miatt.

\subsection{Császármadár megfigyelések 2010-ben}

A 2010-es év tavaszán megfigyeléseinket folytattuk ugyanazon a két mintaterületen belül valamint azok szomszédságában, ahol az előző évben is folyamatosan végeztünk felméréseket.

Az I.-es mintaterïleten elöször március 6-án kutattunk császármadarak után. Kimondottan a déli kitettségü, cserjével borított erdőszéli területeket fésültük át.

2010.III.6-án a kiránduló, szánkózó valamint a nagyon zajos motoros hó szánok miatt az első területen nem folytattunk megfigyeléseket. A délelőtti órákban felkerestük a második biotópot. Hatalmas hóban kellett a területet megközelíteni (0,7-1,0 m közötti a hóréteg vastagsága). Miután sikerült beazonosítani a foglalt kút környékét, császármadarak után keresgéltünk. Madarat sajnos nem láttunk, viszont nagyon sok ürüléket találtunk azon fák alatt, amelyekre a madarak felgallyaztak 
éjszakázás vagy menedék keresés céljából. A továbbiakban átkutattuk a környéket azon hó várak után, amelyekben a császármadarak a fagyos éjszakák ideje alatt összesereglenek (2-3 vagy akár több pár is lehetséges), hogy könnyebben átvészeljék ezen időszakok viszontagságait. A korábban hullott hó valamint a nagy hófúvások következtében kialakult nehézségek miatt aznapi vizsgálataink során nem láttunk császármadarat. Megnyugtató jelenség volt azonban, hogy a császármadarak jelenlétére utaló biztos nyomokat találtunk a környéken. Sajnos ezen a biotópon is motoros hó szánok vonultak át több alkalommal is.

2010.III.7-én, a harmadik területen a vadőr nem a forrás környékén, hanem a tisztás szomszédságában található nyírfák, hamvas égerek valamint a közönséges mogyoró bokrok közvetlen szomszédságában talált kisebb-nagyobb ürülék kupacokat. A kupacok méretei valamint azok száma szerint valószínüleg kevesebb császármadár tartózkodott ezen a területen. Hó várak után a vadőr nem kutatott. A hóréteg vastagsága miatt az elkövetkezendőkbe nem végeztünk megfigyeléseket.

2010.III.27-én délelőtt a foglalt kút környékén még mindég vastag a hótakaró (átlagosan $15-20 \mathrm{~cm}$ ). Jól kivehetőek voltak a régebben használt hóvárak maradványai, nagyon sok ürülékkel a környéken (1. ábra). A hatalmas ürülékkupacok a madarak jelenlétét bizonyítja.

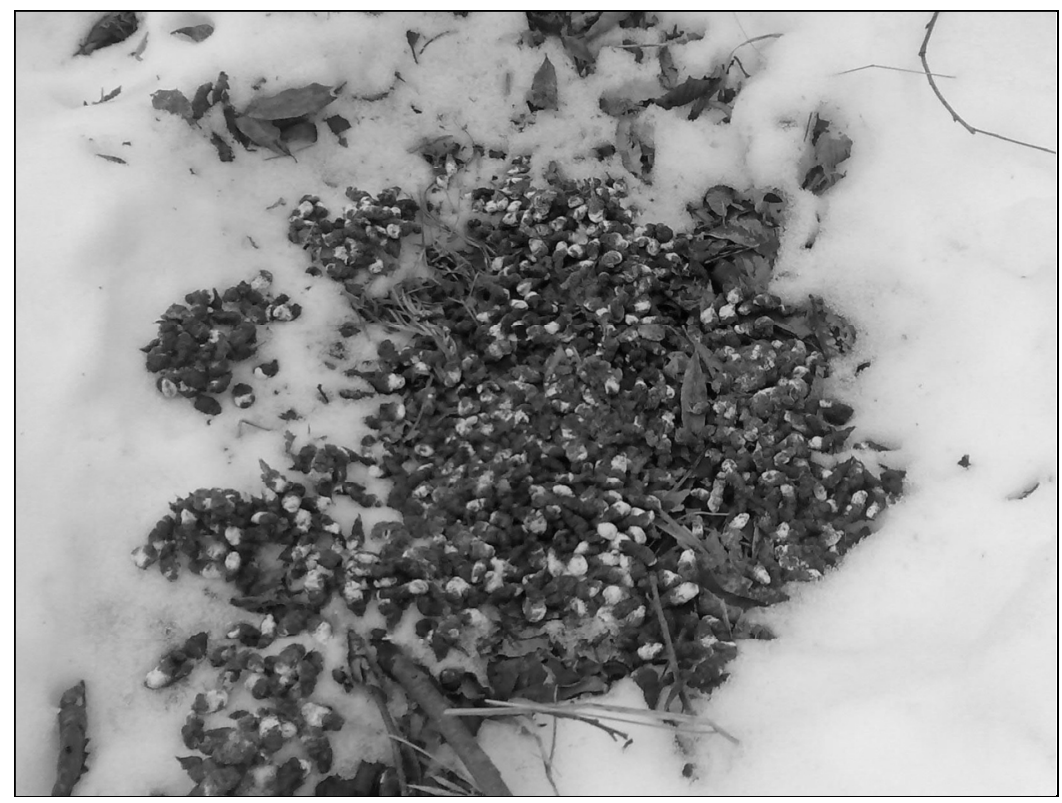

1. ábra: Császármadár ürülék

Figure 1: Excrement of Hazel Grouse

2010.III.27-én kora délután a harmadik területen a régi út környékén hó várakra utaló nyomokat azonosítottak a vadőrök. Császármadarat nem láttak, viszont az ürülék kupacok méretei szerint biztos jelenlétükre következtettek.

2010.IV.-8-án végeztünk utoljára megfigyeléseket. A kettes biotópon belül a hó már csak kisebb nagyobb foltokban van jelen. A foglalt kút szomszédságában kb. két napos ürüléket találtunk. Az ürülék a sürü cserjés szélében volt. Mintát vettem a későbbi kiértékelések céljából, majd tovább vizsgáltuk a területet. 11:20-kor császármadár kakast vettünk észre amint nehézkes röptével a távolabbi állomány irányába menekült. Nem sokkal később a vízmosás irányába egy császármadár tyúkot azonosítottunk a cserjeszint mellett. Rövid időn belül a földön szaladva távozott a cserjeszint takarásába.

2010.VI.8.-án délután a hármas területen folytattuk tovább megfigyeléseinket. 15-16 között a vizenyős terület szomszédságában próbáltam síppal hívni a császármadarakat. Többszöri próbálkozás után egy választ kaptam a gyertyános-nyíres szomszédságából. A madarat sajnos nem sikerült megfigyelnünk. A további várakozás eredményeként kb. 16:30-kor kis távolságra az előbbi megfigyelési területtől császármadár tyúkot vettünk észre. A madár lévén nagyon figyelmes pár perc után a földön futva távozott, a sürü cserje szint alá. Ezek voltak utolsó megfigyeléseink az első mintaterületen belül. 
A II.-es számú mintaterïleten valamivel hamarabb kezdődtek el a vizsgálatok a megközelítési lehetőségek könnyebbsége miatt.

2010.II.27-én próba utat végeztünk a II.-es mintaterületen. A hatalmas hó ellenére körbe jártuk az első, második és harmadik területeket.

Itt nem találtunk semmit. A mintaterület szomszédságában levő mogyoró bokrok alatt barka darabokat és császármadár hullatékot találtunk. A környéken sok farkas valamint róka nyomot figyeltünk meg. Tovább haladva a mintaterülettől dél-nyugat irányba hiúz nyomokat azonosítottunk. Éjszakázó fiatal nyírfákat találtunk, alattuk császármadár ürülékkel. A fentiek függvényében a császármadarak újból megjelentek a korábbi mintaterület szomszédságában, ha nem is a korábban kijelölt biotópokon belül.

2010.III.5-én a három vadőr és jó magam körbe jártuk a területet. Még mindég vastag a hótakaró. Sajnálatos módon a korábbi három biotópon nem találtunk semmit. A második területen a patakhoz közeli területeket fésültük át, de eredménytelenül. Végül a mintaterület határán kívül a tisztás szomszédságában levő mogyoró bokrok alatt észleltünk császármadár hullatékot. Ezen a napon madarat nem láttunk.

2010.III.12-én a hívatásos vadászok a mintaterületen kívüli területeket vizsgálták meg. Friss császármadár nyomot nem találtak. A korábban beazonosított éjszakázó fákat megkeresték és meggyőződtek annak a valószínüségéről, hogy a madarak a környéken tartózkodnak. Több napos hullaték csomókat találtak ezen a környéken, de császármadarat nem sikerült megfigyelniük.

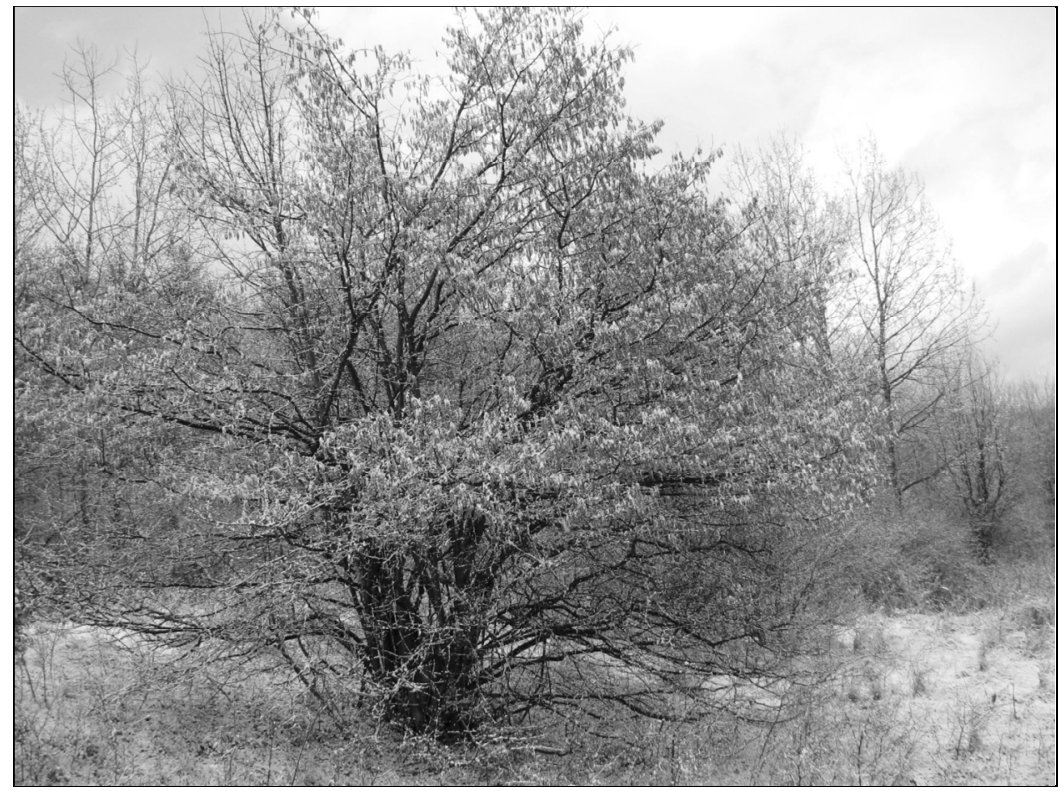

2. ábra: Császármadár élőhely 2010 tavaszán

Figure 2: Habitat of Hazel Grouse in spring of 2010

2010.III.19-én a mintaterületen kívül a tisztás szomszédságában (2. ábra) több rakás hullaték csomót fedeztünk fel, pontosabban 20 rakást egy csoportban. Ezek nem voltak frissek, a tél folyamán itt töltött jelenlétükről tanúskodtak. A környéken sok volt az elfogyasztott mogyoró, éger és füzbarka maradvány. A közelben több téli gallyazó fát azonosítottunk be. A patak partján a kecskefüzek alatt egészen friss császármadár ürüléket figyeltünk meg.

2010.III.28-án a hó már csak nagyobb foltokban volt jelen. A megjelent füves terepen a mogyoró bokrok között több császármadár hullaték rakást vettünk észre. A hullatékok nem voltak frissek, valószínü annak a magyarázata, hogy a téli időszak egy részét a császármadarak ezen a területen töltötték.

2010.IV.9-én a korábban vizsgált területeket utoljára végig jártuk. Több helyen is friss hullatékot figyeltünk meg, minek következtében síppal hívtam a madarakat. Az idős állomány és az út között elterülő cserjés irányából véltünk választ, de madarat nem láttunk. 
2010.IV.9-én 17 óra után, megpróbáltam még egyszer hívni a madarakat. Sípolásomra válaszolt a kakas az út menti cserjésből. Sikerült azonosítani azonban némi várakozás után az idős állomány irányába elrepült. Ez volt az idén megfigyelt utolsó császármadár.

\subsection{A császármadár élőhely kínálatának és élőhely használatának értékelése}

Az előbbiekben felsorolt megfigyeléseimet úgy próbáltam összeállítani, hogy a párzás, csibenevelés és telelés időszakába némi betekintést nyerhessek az élőhely kínálatot és a használatot illetően. Vizsgáltam az erdőtársulások és a császármadár biotópok közötti összefüggéseket. Párhuzamosan végeztem megfigyeléseimet két mintaterület között és azon belül a biotópokon elkülönítve is.

\subsubsection{Az élőhely kínálat}

Megfigyeléseimet két évben végeztem, nagyjából ugyanazon időszakokban. Ez az időbeli egybeesés összehasonlításokra adott lehetőséget és egyben néhány megállapításra is. Mint végkövetkeztetés, nyugodtan merem állítani a zárt szerkezetü erdők fontosságát. Mindkét mintaterületen belül és biotóponként is az elegyes erdők és közvetlen szomszédságuknak kínálata biztosította hosszabb-rövidebb ideig a táplálkozó-és menedéket a madárfajnak. Ezen élőhely típusok területének nagysága éveken keresztül változatlanul marad, ami tulajdonképpen azt jelenti, hogy táplálék és menedékhely kínálatuk részaránya változatlan.

Az I-es mintaterület első számú biotópja 20,2 hektáron a kövezett erdei autóúttól délnyugatra eső területen a Bilibók puszta szomszédságában található. A nagyobb kiterjedésü pusztáig kisebb-nagyobb tisztások fordulnak elő egymást váltogatva a sokszintü erdőszegélyig. A kis tisztásokat $60-70 \mathrm{~cm}$ magas lágyszárúak borították, csalán, páfrány, erdei nebáncsvirág. A terület $890-1000$ m-es t. sz. feletti magasságok között váltakozik. Az alomtakaró itt folytonosan szabályos, az állományon belüli fajok megoszlása 70\%-os közönséges lucfenyő 56\%-os záródással és $30 \%$-os jegenyefenyő 24\%-os záródással. Az állomány átlagéletkora 65 év körüli. A cserjeszintet a közönséges mogyoró, sóskaborbolya, egybibés galagonya, földi szeder, hamvas szeder és málna alkották. A már említett Bilibók pusztája szélében szórványosan a gyepürózsa és a közönséges boróka fordul elő.

A második biotóp valamivel magasabban fekszik, 900-1050 m-es t. sz. feletti magasságok között 31,1 hektáros területen. Az anyakőzet részlegesen látszik, mohával borított, ahol a szórványosan kidőlt, helyben maradt fák úgyszintén megtalálhatók. Állományalkotó fafaj a lucfenyő 90\%-ban, 10\%-ban pedig a jegenyefenyő. A lucfenyők eltérő életkorúak, 95 évesek 16\%-os záródással és 70 évesek 56\%-os záródással. Ami a jegenyefenyők életkorát illeti, átlagosan 70 évesek 8\%-os záródást mutatva. A terület nyugati peremén felhagyott erdei út halad át, két oldalt elegy fafajokkal, mint amilyen a nyír, gyertyán, bükk és elszórtan a rezgőnyár. A terület keleti oldalán vízmosás található, melyben előfordul a mézgás éger és a kecskefüz. A cserjeszintet közönséges mogyoró, málna, sóskaborbolya, egybibés galagonya, földi szeder, hamvas szeder és málna alkotja. Szórványosan elöfordul a gyepürózsa és a közönséges boróka, a nyitottabb területeken.

A harmadik biotóp 950 és 1150 m-es t. sz. feletti magasságon található. Az anyakőzet itt is nagyjából megfigyelhető, melyet $30-40 \%$-os arányban moha borít. Állományalkotó fafajok a lucfenyő 50\%-ban és a bükk szintén 50\%-ban. Életkoruk átlag 70 év, 40\%-os záródást mutatva. A patak ezt a területet kelet majd hirtelen fordulattal délnyugat irányba határolja. A forrásvidék a terület északkeleti csücskén található, melynek következtében a környék állandóan vizenyős, nedves. A vizsgált terület növénytakarója igen változatos. A környéken megtalálható az állományalkotó fafajok mellett a nyír szálanként vagy kisebb - 
nagyobb csoportokba, a gyertyán, hamvas éger, madárberkenye, erdei vadalma, rezgő nyár és a mézgás éger. Ami a cserjeszintet illeti, szórványosan jelen van a málna, valamint elszórtan kisebb-nagyobb csoportokat képezve a hamvas szeder, földi szeder. Az út menti cserjeszintben nagy gyakorisággal fordul elő a fekete bodza, bibircses kecskerágó és a veresgyürüs som. Nagy mennyiségben található meg a mogyoró az erdő menti tisztásokon. Szórványosan, csoportokat képezve a közönséges boróka és a gyepürózsa fordul elő az erdőszegéllyel párhuzamosan.

A megfigyelt császármadarak 2001-ben és 2002-ben az I-es mintaterület 65,9 hektárt kitevő e három biotópján belül tartózkodtak - táplálkoztak, porfürdőztek, kerestek menedéket a megfigyelési időszak alatt. A vizsgálati területekre jellemző volt a nagyfokú diverzitás. A vizenyős, nyirkos erdővel borított területek részaránya megközelítette a 80\%-ot, ami 52,72 hektárnak felelt meg, míg az utak, útpadkák, erdőszegélyek, apró tisztások 20\%-ot tettek ki 13,18 hektáron. Az erdőállományt alkotó fafajok életkora 65 és 95 év között váltakozik, aminek következtében érthető a hozzávetőlegesen felbecsült 35\%-os cserjeszint jelenléte az erdőállományon belül. Végső fokon elmondható, hogy a faállomány változatos koronaszintje (45\%), az erdőállományon belüli változatos cserjeszint (35\%), az erdőszegélyek, tisztások, utak, útpadkák a szomszédos cserjésekkel valamint a vizenyős területek (20\%) biztosították az élőhely kínálatot a császármadarak számára ezen a mintaterületen belül.

A 2009-ben és 2010-ben megfigyelt császármadarak az I.-es mintaterületnek csak a 45,7 hektárt kitevő korábban kijelölt második és harmadik biotópján belül táplálkoztak és kerestek menedéket a megfigyelési időszak során. Az I.-es mintaterület első számú biotópja 20,2 hektárján, - amely a Bilibók nevü puszta szomszédságában található - valamint közvetlen szomszédságában olyan intenzív erdőhasználati tevékenységeket folytattak az utóbbi tíz évben, amely valamelyest megváltoztatva az állomány összetételét. Mindez azonban nem jelentett akkora veszélyt, mint a folyamatos zavarás, amelynek hatására az első biotópból eltünt a császármadár.

A II-es mintaterület eredendő, 2001-es állapotát az alábbiakkal jellemezhetjük: Az első biotópja t. sz. felett 950-1100 m közötti magasságokon található 16,7 hektáros területen. Az anyakőzet részlegesen látszik, gyakori a helyben maradt kidőlt fák jelenléte is. A köveket moha borítja. A területen megtalálható állomány eredete természetes, 50\%-ban 100 éves lucfenyő és 30\%-ban szintén 100 éves jegenye fenyves. A lucfenyők záródása 40\%-os, míg a jegenyefenyőké 24\%. Ennek a biotópnak az északnyugati csücskében egy átlagosan 55 év körüli elegyes luc-jegenye fenyves faállomány található 8\%-os záródással. Az elegyedési részarányuk 10-10\%-ot tesz ki. A biotóp délkeleten határos egy bozótos kaszálóval. Ezen a területen elszórtan megtalálható a nyír, gyertyán és a hegyi juhar. Nagyobb részarányba a bükk van jelen, míg a kecskefüz egy-egy példánnyal teszi változatosabbá ezt a területet. A délkeleti csücskén kövezett erdei út található. Az erdei autóút változatos cserjeszinttel közvetlen határos. A közönséges mogyoró tömegesen fordul elö, míg az állandóan vizenyős területeken megtalálható a mézgás éger és a rezgő nyár.

A II-es mintaterület második biotópja 980 méteres t. sz. feletti magasságon található meg, összesen 5,2 ha-on. Az anyakőzet nem annyira látható mint az első területen. Az erdőállományon belüli fafajok aránya 60\%-os lucfenyő és $40 \%$-os jegenyefenyő, 80 illetve 85 éves átlag életkorral. Záródásuk 32\%. Mint elegy fafaj a bükk, gyertyán, és nagyon szórványosan a nyír van jelen. A területen áthalad az előbb leirt autóút úgy $1000 \mathrm{~m}$ - es t. sz. feletti magasságban. Az út mentén megtalálható a mogyoró, a magasra megnőtt málna és a földi szeder. Még jelen van a rekettyefüz, közönséges boróka és a gyepürózsa.

A harmadik biotóp valamivel magasabban fekszik, 1050 és 1300 méteres t. sz. feletti magasságok között váltakozva 18,5 hektáros területen.. Nagyon gyakori a helyben maradt 
kidőlt fák jelenléte. Az állományon belüli fajok aránya 60\%-ban lucfenyő, 20\%-ban jegenyefenyő és 20\%-ban bükk. A lucfenyők 80 éves átlag életkorúak és 48\%-os záródást mutatnak, míg a jegenyefenyők 85 év körüliek 32\%-os záródással. Szálanként vagy nagyon kis csoportokban a bükk és a gyertyán található meg, mint elegy fafaj átlagos 25 éves életkorral és 9\%-os záródással. Itt már külön cserje szintet nem lehet emlegetni, ami alól kivételt képez az erdei tisztással határos erdőszegély. Ezen a részen hangsúlyozottan a bükk felújulása, a málna és a földi szeder jelenléte volt észlelhető. Ami még figyelemreméltó volt, az a közelben megtalálható tisztáson jelenlevő nagyszámú mogyoróbokor jelenléte és a sok hangyaboly előfordulása.

$\mathrm{Az}$ első mintaterülethez hasonlóan a másodikat is a változatosság jellemezte. A megfigyelt biotópok egy 40,4 hektáros területet foglaltak magukba, melyekből az erdővel borított területek részaránya a fentiek alapján 83\%-nak felelt meg, 33,5 hektárt kitéve. A kövezett erdei út a két oldalt megtalálható gazdag cserjeszinttel, a tisztások melletti erdőszegélyek, a bozótos területek egy keskeny sávja valamint egy-két vizenyősebb terület 17\%-on képezték a megfigyelések egy részét 6,9 hektáron. Az átlagosan magas életkorú faállomány (80-100 év) alatt melyek az erdőállományt alkotják ezeken a területeken is, megtalálható egy szegényesebb cserjeszint, körülbelül egy 25\%-os jelenléttel. Így összességében a változatos erdőállomány koronaszintje (58\%), az erdőállomány alatti cserjeszint (25\%), valamint az erdőszegélyek, utak, útszegélyek és vizenyős területek (17\%) képezték a leggyakoribb előfordulási és megfigyelési területeket ezen mintaterület esetében is.

A II.- es mintaterületen és annak szomszédságában elvégzett erdőhasználati tevékenység 2009-re nagyon megváltoztatták az élöhelyi adottságokat. Mindhárom korábban kijelölt biotópon lecsökkent az erdőállomány, tönkre ment a korábban létező cserjeszint. Megmaradtak a szomszédos kaszálókon tenyésző mogyoró bokrok, szabadállású nyírek, valamint kecskefüzek. A megváltozott körülményeknek megfelelően eltüntek a császármadarak is a területről. A megfigyelt biotópok egy 40,4 hektáros területet foglaltak magukba, amelyből jelenleg az erdővel borított területek részaránya kb. 35\%-nak felel meg, 14,14 hektárt kitéve. Hozzávetőlegesen a megmaradt és fejlődésnek indult cserjeszintet 25\%ra becsülhető az állományon belül. A fentiek következtében elmondható, hogy a megmaradt faállomány koronaszintjei (35\%), a kialakulóban levő cserjeszint (25\%) és a finomfeltáró hálózatot alkotó utak, útpadkák, apró tisztások, erdőszegélyek és a vizenyős területek (40\%) alkották e mintaterület jelenlegi élőhelyi kínálatát.

2009. augusztus eleje és december vége közötti időszakban valamint 2010 tavaszán végezett megfigyeléseink lehetőséget adtak a korábban elvégzett felmérésekkel való összehasonlításra is. Következtetésképpen merem állítani, hogy a zárt szerkezetű erdők továbbra is nagyon fontosak a császármadarak számára. Mindkét mintaterületen belül és biotóponként is a maradék elegyes erdők és közvetlen szomszédságuk biztosította a táplálkozó és menedéket biztosító területet e madarak számára. Ezzel szembe a szünni nem akaró zavaró antropogén tevékenységek eredményeként szerkezeti és minőségi élőhely változások mentek végbe, minek következtében a táplálék és menedékhely kínálata és ennek használata közötti részarányában is változások keletkeztek.

Az ízeltlábú fauna mind fajban, mind egyedben eléggé gazdag mind a két mintaterület esetében. Erre enged következtetni az általam elkezdett ízeltlábú táplálékforrás-kínálat vizsgálat első eredményei. Sajnos külső okok miatt kudarcba fulladt a vizsgálat teljes körü megvalósítása. (A kiránduló és gombászó emberek a BARBER-csapdasorokat tönkretették.) Mindezek ellenére állítható, hogy az ízeltlábú faj és egyed gazdagság arra enged következtetni, hogy a császármadár tápláléka márciustól-szeptemberig állati eredetü táplálékból is biztosítva van. 


\subsubsection{Az élőhely használat}

A felméréseim eredményeként 2001-ben és 2002-ben a két mintaterületen kb. négy részpopulációt különíthettünk el. Egy-egy részpopuláció 2-4 egyedből állt, amire a madár megfigyelésekből következtettünk. A részpopulációk a mintaterületeken belül elkülönítve fordultak elö egy-egy kisebb habitaton belül. 2009-ben és 2010-ben 8 részpopulációt különíthettünk el.

A császármadár élöhely használata vizsgálata azt mutatta, hogy a faj egyedei a térségben a zárt állományszerkezetű erdők szélén és a közvetlen szomszédságában található tisztásokon fordultak elő a leggyakrabban. Előfordulási területe az üde, félnedves-nedves elegyes luc-jegenye fenyves termőhelyeken optimális, függetlenül attól, hogy a termőhelyeken jelenleg még milyen elegy fafaj található kisebb-nagyobb részarányban. A kimondottan idős állományokban csak ritkán - inkább átmenetileg - tartózkodtak, amint egyik tisztásról a másikra igyekeztek a földön futva, vagy a koronaszint magasságában repülve kisebb-nagyobb távolságok megtételével. Kiváló védelmet biztosító színezete és nagyon elővigyázatos magatartása miatt nehéz volt a madarak megfigyelése a párzási időszakban, amikor a környezetüket a viszonylag már magas fedettség jellemezte. A megfigyelések alapján kellően hasznosították ezen időszakban az erdőszegélyeket, itt találva megfelelő mennyiségü táplálékot a cserjeszint rügyei és hajtásai között. A költés, fészkelés ideje alatt kimondottan a sürü borítású cserjeszintet és az erdőállomány szegélyeket részesítették előnybe. A kora őszi időszakban szintén itt fordultak elö a leggyakrabban, általában a vizenyős-tocsogós területek szomszédságában, ahol a szalamandra és a gyepi béka is elöfordult.

Így főleg a nedvesebb területek dúsabb növényzettel borított területei biztosítottak táplálékot és rejtőzködési lehetőséget. A nyár folyamán úgyszintén kihasználták a bemutatott területeknek ezen adottságait. Különbség csak a csibenevelés időszakában adódott, mikor gyakoribb volt a tisztásokon való megjelenés az ízeltlábúak után kutatva. Ezen tevékenységüket nagyon óvatosan és körültekintéssel végezték, felhasználva erre a célra az út menti fiatalos, bokros, cserjeszint nyújtotta védelmet. Összességében elmondható, hogy a császármadár a biztos rejtőzködési lehetőségeket nyújtó területeket választotta a párzási és a nyári időszak alatt. Változott a helyzet az ősz beálltával. A lombhullással egy időben nagyon megfogyatkozott az aljnövényzet és eltünt a dús lombtakaró. A terület fokozatosan csupasszá vált, aminek következtében eltünt a bőséges táplálék kínálat és a takarás. Az ősz vége felé az addig megfigyelt területekről a császármadarak eltüntek. Beigazolódottnak látszik TEIDOFF (1951, idézi CzÁJLIK, 1982) állítása, miszerint késő ősszel a császármadarak elhagyják tartózkodási területüket. Mindezek után olyan helyen pillantottam meg ahol eddig nem tartózkodott. Erre a változásra IVANTER (1962) is utal. Sőt mi több VOLKOV (1968, idézi CzÁJLIK, 1982) azt a tényt állapította meg, hogy az összel kiválasztott tartózkodási területet a császármadár télen is megtartja. Ezek az állítások az én megfigyeléseim által is beigazolódtak. Enyhén északi kitettségü területeket választottak a madarak, ahol megtalálható a mézgás éger, kecskefüz, nyír és a mogyoró. Megfigyeléseim szerint az élőhely változást befolyásolták az antropogén tényezők is. A zárt állományokat, erdei utakat, tisztásokat és gyepes területeket inkább a nyár folyamán, nyár végén, olykor téli időszakban keresték fel a madarak, eleinte csökkenő, majd növekvő arányban. A mogyoró bokrokkal sủrűn benőtt tisztásokat, melyek a zárt erdőállományok szomszédságában találhatók, a császármadarak inkább a tél folyamán használták, részesítették előnybe. Erre utalnak a sorozatosan megtalált ürülékrakások az adott területen. Megfigyeléseim egybevágnak IVANTER (1962) azon állításával miszerint: „minden párnak vagy családnak meg van az az elegendö kiterjedésü erdö területe, ahol az egész téli idöszakban tartózkodnak." Ugyanakkor IVANTER (1962) megemlíti azt is, hogy a 
császármadarak a táplálék adottságoknak megfelelően biotópjukon belül évszakonként helyet változtatnak. A biotóp határát csak nagyon erős hatásra hagyják el. Ezt igazolja az a tény, hogy az I. mintaterületen belüli első biotópra és a II. mintaterület egyes és kettes biotópjairól eltünnek a madarak nyár közepére. Eltünésük nem annyira a táplálék adottságok leszükülése miatt történtek, hanem a zavaró tényezők hatására. Ilyen tényező a legeltetés, turizmus és erdei üdülő házak építése. Érdekes módon télen, mikor ezek a tevékenységek megszünnek, jelenlétük újból igazolt az adott területeken a megtalált császármadár ürülékek szerint. A táplálék adottságoknak megfelelően történő helyváltoztatást és egyben élöhely használatot igazolják azok a megfigyelések, mikor a téli időszakban a madarak a nyíltabb területek mogyoróval, nyírrel borított övezeteibe vonulnak, vagy a kecske és rekettyefüzzel szegélyezett patak és út menti területeken tünik fel. Mindezek függvényében és az elmondottak alapján, ha egy élőhely használati sorrendet akarnánk felállítani, akkor az az alábbi lenne: vizenyős zárt erdő szerkezet, erdő szegély tisztással, utak - útszegélyek, patak menti területek és mogyoróval, cserjékkel gazdagon borított bozótos területek.

\subsubsection{A császármadár élőhely választása}

Az élőhely kínálat és élőhely használat dominancia értékeinek számszerüsített ismeretében a császármadár élőhely választását, azaz preferenciáját IVLEV-index-szel adhatjuk meg.

$\mathrm{Az}$ erdőállományok, cserjeszintek, utak, erdőszegélyek, a tisztások, valamint a vizenyős, nedves területek változatlanok voltak. Területnagyságuk állandó volt, így a császármadár számára egész évben biztosítják a folyamatos élőhely kínálatot.

Ennek ellenére a faj a három teljes vizsgálati év folyamán nem mutatott pozitív értékeket az erdöállományokat (IVLEV-index I. mintaterület - 2001: -0,24; 2002: -0,59; 2009: -0,44; II. mintaterület - 2001: -0,51; 2002: -0,34) és az azon belül megtalálható cserjeszintet (IVLEV-index I. mintaterület - 2001: $-0,11 ; 2002$ : $-0,19$; 2009: $-0,15$; II. mintaterület 2001:-0,14; 2002:-0,27) illetően.

\section{1. táblázat: Az élőhely kínálat, a császármadár élőhely használata és választása az I-es mintaterületen belül, 2001-ben}

Table 1: Habitat availability, habitat use and habitat selection by Hazel Grouse on the Plot I. in 2001

\begin{tabular}{|l|c|c|c|c|c|}
\hline \multirow{2}{*}{ Élőhely - Habitat } & \multicolumn{2}{|c|}{$\begin{array}{c}\text { Élőhely kínálat } \\
\text { Habitat availability }\end{array}$} & \multicolumn{2}{c|}{$\begin{array}{c}\text { Élőhely használat } \\
\text { Habitat use }\end{array}$} & $\begin{array}{c}\text { Élöhely választás } \\
\text { Habitat preference } \\
\text { IVLEV-index }\end{array}$ \\
\cline { 2 - 5 } & ha & $\mathbf{\%}$ & $\mathbf{d b}$ & $\mathbf{\%}$ & $-0,24$ \\
\hline $\begin{array}{l}\text { Erdöállomány } \\
\text { Forest }\end{array}$ & 29,66 & 45,00 & 5 & 27,80 & $-0,11$ \\
\hline $\begin{array}{l}\text { Cserjeszint } \\
\text { Shrub layer }\end{array}$ & 23,06 & 35,00 & 5 & 27,80 & 0,42 \\
\hline $\begin{array}{l}\text { Utak, erdöszegélyek } \\
\text { Roads, forest margins }\end{array}$ & 2,97 & 4,50 & 2 & 11,10 & 0,13 \\
\hline $\begin{array}{l}\text { Tisztások cserjékkel } \\
\text { Clearing with shrubs }\end{array}$ & 5,60 & 8,50 & 2 & 11,10 & 0,52 \\
\hline $\begin{array}{l}\text { Vizenyős területek } \\
\text { Watery area }\end{array}$ & 4,61 & 7,00 & 4 & 22,20 & \\
\hline Mindösszesen - Total & $\mathbf{6 5 , 9 0}$ & $\mathbf{1 0 0 , 0 0}$ & $\mathbf{1 8}$ & $\mathbf{1 0 0 , 0 0}$ & \\
\hline
\end{tabular}


2. táblázat: Az élőhely kínálat, a császármadár élőhely használata és választása az I-es mintaterületen belül, 2002-ben

Table 2: Habitat availability, habitat use and habitat selection by Hazel Grouse on the Plot I. in 2002

\begin{tabular}{|c|c|c|c|c|c|}
\hline \multirow[t]{2}{*}{ Élőhely - Habitat } & \multicolumn{2}{|c|}{$\begin{array}{c}\text { Élóhely kínálat Habitat } \\
\text { availability }\end{array}$} & \multicolumn{2}{|c|}{$\begin{array}{c}\text { Élőhely használat } \\
\text { Habitat use }\end{array}$} & \multirow{2}{*}{$\begin{array}{l}\text { Élőhely választás } \\
\text { Habitat preference } \\
\text { IVLEV-index }\end{array}$} \\
\hline & ha & $\%$ & $\mathbf{d b}$ & $\%$ & \\
\hline $\begin{array}{l}\text { Erdőállomány } \\
\text { Forest }\end{array}$ & 29,66 & 45,00 & 2 & 11,76 & $-0,59$ \\
\hline $\begin{array}{l}\text { Cserjeszint } \\
\text { Shrub layer }\end{array}$ & 23,06 & 35,00 & 4 & 23,53 & $-0,19$ \\
\hline $\begin{array}{l}\text { Utak, erdőszegélyek } \\
\text { Roads, forest margins }\end{array}$ & 2,97 & 4,50 & 3 & 17,65 & 0,17 \\
\hline $\begin{array}{l}\text { Tisztások cserjékkel } \\
\text { Clearing with shrubs }\end{array}$ & 5,60 & 8,50 & 4 & 23,53 & 0,47 \\
\hline $\begin{array}{l}\text { Vizenyős területek } \\
\text { Watery area }\end{array}$ & 4,61 & 7,00 & 4 & 23,53 & 0,54 \\
\hline Mindösszesen - Total & 65,90 & $\overline{100,00}$ & 17 & 100,00 & \\
\hline
\end{tabular}

3. táblázat: Az élőhely kínálat, a császármadár élőhely használata és választása az I-es mintaterületen belül, 2009-ben

Table 3: Habitat availability, habitat use and habitat selection by Hazel Grouse on the Plot I. in 2009

\begin{tabular}{|l|c|c|c|c|c|}
\hline \multirow{2}{*}{ Élöhely - Habitat } & \multicolumn{2}{|c|}{$\begin{array}{c}\text { Élőhely kínálat Habitat } \\
\text { availability }\end{array}$} & \multicolumn{2}{c|}{$\begin{array}{c}\text { Élöhely használat } \\
\text { Habitat use }\end{array}$} & $\begin{array}{c}\text { Élöhely választás } \\
\text { Habitat preference } \\
\text { IVLEV-index }\end{array}$ \\
\cline { 2 - 5 } & ha & $\mathbf{\%}$ & $\mathbf{d b}$ & $\mathbf{\%}$ & $-0,44$ \\
\hline $\begin{array}{l}\text { Erdóállomány } \\
\text { Forest }\end{array}$ & 20,55 & 45,00 & 8 & 17,39 & $-0,15$ \\
\hline $\begin{array}{l}\text { Cserjeszint } \\
\text { Shrub layer }\end{array}$ & 16,00 & 35,00 & 12 & 26,09 & 0,66 \\
\hline $\begin{array}{l}\text { Utak, erdószegélyek } \\
\text { Roads, forest margins }\end{array}$ & 2,06 & 4,50 & 10 & 21,74 & 0,34 \\
\hline $\begin{array}{l}\text { Tisztások cserjékkel } \\
\text { Clearing with shrubs }\end{array}$ & 3,89 & 8,50 & 8 & 17,39 & 0,06 \\
\hline $\begin{array}{l}\text { Vizenyös területek } \\
\text { Watery area }\end{array}$ & 3,20 & 7,00 & 8 & 17,39 & \\
\hline Mindösszesen - Total & $\mathbf{4 5 , 7 0}$ & $\mathbf{1 0 0 , 0 0}$ & $\mathbf{4 6}$ & $\mathbf{1 0 0 , 0 0}$ & \\
\hline
\end{tabular}

4. táblázat: Az élőhely kínálat, a császármadár élőhely használata és választása a II-es mintaterületen belül, 2001-ben

Table 4: Habitat availability, habitat use and habitat selection by Hazel Grouse on the Plot II. in 2001

\begin{tabular}{|l|c|c|c|c|c|}
\hline \multirow{2}{*}{ Élőhely - Habitat } & \multicolumn{2}{|c|}{$\begin{array}{c}\text { Élőhely kínálat Habitat } \\
\text { availability }\end{array}$} & \multicolumn{2}{c|}{$\begin{array}{c}\text { Élőhely használat } \\
\text { Habitat use }\end{array}$} & $\begin{array}{c}\text { Élöhely választás } \\
\text { Habitat preference } \\
\text { IVLEV-index }\end{array}$ \\
\cline { 2 - 5 } & ha & $\mathbf{\%}$ & $\mathbf{d b}$ & $\%$ & $-0,51$ \\
\hline $\begin{array}{l}\text { Erdóállomány } \\
\text { Forest }\end{array}$ & 23,41 & 58,00 & 3 & 18,75 & $-0,14$ \\
\hline $\begin{array}{l}\text { Cserjeszint } \\
\text { Shrub layer }\end{array}$ & 10,09 & 25,00 & 3 & 18,75 & 0,52 \\
\hline $\begin{array}{l}\text { Utak, erdőszegélyek } \\
\text { Roads, forest margins }\end{array}$ & 4,87 & 12,00 & 6 & 37,50 & 0,57 \\
\hline $\begin{array}{l}\text { Tisztások cserjékkel } \\
\text { Clearing with shrubs }\end{array}$ & 1,38 & 3,40 & 2 & 12,50 & 0,77 \\
\hline $\begin{array}{l}\text { Vizenyós területek } \\
\text { Watery area }\end{array}$ & 0,65 & 1,600 & 2 & 12,50 & \\
\hline Mindösszesen - Total & $\mathbf{4 0 , 4 0}$ & $\mathbf{1 0 0 , 0 0}$ & $\mathbf{1 6}$ & $\mathbf{1 0 0 , 0 0}$ & \\
\hline
\end{tabular}




\section{5. táblázat: Az élőhely kínálat, a császármadár élőhely használata és választása a II-es mintaterületen belül, 2002-ben}

Table 5: Habitat availability, habitat use and habitat selection by Hazel Grouse on the II. plot in 2002

\begin{tabular}{|c|c|c|c|c|c|}
\hline \multirow[t]{2}{*}{ Élőhely - Habitat } & \multicolumn{2}{|c|}{$\begin{array}{l}\text { Élőhely kínálat } \\
\text { Habitat availability }\end{array}$} & \multicolumn{2}{|c|}{$\begin{array}{c}\text { Élőhely használat } \\
\text { Habitat use }\end{array}$} & \multirow{2}{*}{$\begin{array}{l}\text { Élőhely választás } \\
\text { Habitat preference } \\
\text { IVLEV-index }\end{array}$} \\
\hline & ha & $\%$ & db & $\%$ & \\
\hline $\begin{array}{l}\text { Erdőállomány } \\
\text { Forest }\end{array}$ & 23,41 & 58,00 & 4 & 28,57 & $-0,34$ \\
\hline $\begin{array}{l}\text { Cserjeszint } \\
\text { Shrub layer }\end{array}$ & 10,09 & 25,00 & 2 & 14,29 & $-0,27$ \\
\hline $\begin{array}{l}\text { Utak, erdőszegélyek } \\
\text { Roads, forest margins }\end{array}$ & 4,87 & 12,00 & 2 & 14,29 & 0,09 \\
\hline $\begin{array}{l}\text { Tisztások cserjékkel } \\
\text { Clearing with shrubs }\end{array}$ & 1,38 & 3,40 & 5 & 35,71 & 0,83 \\
\hline $\begin{array}{l}\text { Vizenyős területek } \\
\text { Watery area }\end{array}$ & 0,65 & 1,60 & 1 & 7,14 & 0,63 \\
\hline Mindösszesen - Total & 40,40 & 100,00 & 14 & 100,00 & \\
\hline
\end{tabular}

\section{6. táblázat: Az élőhely kínálat, a császármadár élőhely használata és választása a II-es} mintaterületen belül, 2009-ben

Table 6: Habitat availability, habitat use and habitat selection by Hazel Grouse on the II. plot in 2009

\begin{tabular}{|c|c|c|c|c|c|}
\hline \multirow[t]{2}{*}{ Élőhely - Habitat } & \multicolumn{2}{|c|}{$\begin{array}{c}\text { Élőhely kínálat } \\
\text { Habitat availability }\end{array}$} & \multicolumn{2}{|c|}{$\begin{array}{c}\text { Élőhely használat } \\
\text { Habitat use }\end{array}$} & \multirow{2}{*}{$\begin{array}{c}\text { Élőhely választás } \\
\text { Habitat preference } \\
\text { IVLEV-index }\end{array}$} \\
\hline & ha & $\%$ & $\mathbf{d b}$ & $\%$ & \\
\hline $\begin{array}{l}\text { Erdőállomány } \\
\text { Forest }\end{array}$ & 14,14 & 35,00 & - & - & - \\
\hline $\begin{array}{l}\text { Cserjeszint } \\
\text { Shrub layer }\end{array}$ & 10,10 & 25,00 & - & - & - \\
\hline $\begin{array}{l}\text { Utak, erdőszegélyek } \\
\text { Roads, forest margins }\end{array}$ & 7,27 & 18,00 & - & - & - \\
\hline $\begin{array}{l}\text { Tisztások cserjékkel } \\
\text { Clearing with shrubs }\end{array}$ & 8,08 & 20,00 & - & - & - \\
\hline $\begin{array}{l}\text { Vizenyős területek } \\
\text { Watery area }\end{array}$ & 0,81 & 2,00 & - & - & - \\
\hline Mindösszesen - Total & $\mathbf{4 0 , 4 0}$ & $\mathbf{1 0 0 , 0 0}$ & - & - & \\
\hline
\end{tabular}

Preferálta azonban az utakat és a közvetlen szomszédságukban megtalálható változatos cserjeszegélyeket (IVLEV-index I. mintaterület - 2001: 0,42; 2002: 0,17; 2009: 0,66; II. mintaterület - 2001: 0,52; 2002: 0,09). Magas preferenciákat mutatott, ami a tisztások cserjével borított területeit illeti (IVLEV-index I. mintaterület - 2001: 0,13; 2002: 0,47; 2009: 0,34; II. mintaterület - 2001: 0,57; 2002: 0,83) és maximális értékekkel jellemezte a nedves, üde vizenyös területek övezetét (IVLEV-index I. mintaterület - 2001: 0,52; 2002: 0,54; 2009: 0,06; II. mintaterület - 2001: 0,77; 2002: 0,73), ami egyben a faj tartós vonzódását igazolja ehhez az élőhelyhez.

Összességében elmondható, hogy a jól strukturált, mozaikszerüen elhelyezkedö élöhelytípusok komplexe a kedvezö a számára, azaz a kellö mértékü vertikális és horizontális élőhely diverzitás, ami megfelelö búvóhelyet és táplálkozási lehetőséget is biztosít a számára. 


\section{A FAJJAL KAPCSOLATOS LOKÁLIS VÉDELMI PROBLÉMÁK}

A császármadarak esetében is - mint bármelyik más vadfajnál - több olyan zavaró jelenség létezik, amelyek a meglévő populációkat időnként vagy folyamatosan negatív irányban befolyásolják. Ezen jelenségeket előidézheti az ember saját tevékenysége révén, vagy az olyan természetes katasztrófák, mint a széldöntések vagy széltörések sorozatos megnyilvánulása.

Az emberi hatások közül beszélhetünk olyan tevékenységekről, amelyek időszakosan, elöre jól meghatározható terminusok között avatkoznak be a madarak életébe. Ilyen a vadászat szezonális jellege. De ugyanakkor vannak olyan gazdasági jellegü tevékenységek, amelyek a párzás, költés, csibenevelés vagy a telelés ideje alatt drasztikus károkat okozhatnak. Ide sorolhatjuk a legeltetést, a terelést, a fakitermelést, a turizmust (beleértve a gomba és más gyümölcsök gyüjtését) és az erdei építkezéseket. A természeti katasztrófák sajnos évszaktól és az emberi tevékenységektől függetlenül időről-időre megjelennek, tönkretéve az élőhely szerkezetét, olykor kemény veszteségeket előidézve magában a vadállományban is.

\subsection{A császármadár és a vadászat}

A császármadár rejtett életmódot folytat, terepen nehezen észlelhető. Mindehhez társul a megfelelő színủ tollazat, amely az év minden időszakában megfelelő álcát biztosít számára. Párkapcsolatát monogámia jellemzi, ami egy évnyi időre tartja össze a kakast és a tyúkot. Mivel már az ősz folyamán párba állnak, nincs szükség olyan dürgési ismerkedési ceremóniára, mint a siketfajd vagy a nyírfajd esetében (FARAGÓ, 2002). Becserkészni egyáltalán nem lehet, az egyetlen eszköz, amivel be lehet csalni, be lehet csapni, az a hívó síp.

Vadászata Romániában szeptember 15. és december 15. között engedélyezett, az érvényes jogszabályoknak megfelelően. Véleményem szerint arra kell összpontosítani inkább a figyelmet, hogy a meglevő elméleti szaktudás és a vadászatban jártas, gyakorlatias magatartás együttesével a még ismeretlen populációkat és biotópokat kutassák fel a szakemberek. A vadászati nyomás viszonylag alacsony e faj tekintetében, állományait nem a vadászat veszélyezteti.

\subsection{A császármadár populációkat negatívan befolyásoló tényezők}

Ezen témakörön belül olyan alapvető problémát kell megvizsgálnunk, amelyek közvetve vagy közvetlenül befolyásolják a madárfaj populációnagyságának változásait. Ezek a legeltetés terelés, az erdőkitermelés, a turizmus és a természeti katasztrófák, valamint a predáció.

\subsubsection{A legeltetés hatása}

A legeltetésnek a mi tájainkon egy közismert formája van, a havasi legeltetés. Az 1980-1990es években a mezőgazdasági üzemek tulajdonában levő legelökön a termö gyepterületek termésének mintegy 60\%-át legeltetve hasznosították, 40\%-át pedig kaszálták. A rendszerváltást követően a nagyüzemek tulajdonában levő legelőket felaprózták és visszaszolgáltatták jogos tulajdonosaiknak. Akárcsak az erdőket, a legelöket is sok tulajdonos birtokolja, aminek következtében elkezdődött a területek különböző hasznosítása. Akadtak tulajdonosok, akik bérbe adták e területeiket, mások lekaszálták vagy egyszerüen felhagytak 
kezelésükkel, karbantartásukkal. A bérbe adott legelökön az 1990-es évek után újból megjelentek a gulyák és nyájak. A kiválasztott két mintaterületen belül nem voltak legelők, viszont azok szomszédságában igen. Éppen ezért fontos annak a vizsgálata, hogy a legelő állatok és az őket felügyelő pásztorkutyák milyen mértékben befolyásolták a császármadár állomány alakulását az utóbbi tíz évben.

Az I.-es mintaterület közvetlen szomszédságában a Hírtelen és Bilibók pusztákon 1999-ben három hivatalosan bejegyzett juhnyáj létezett (Csíkszereda Megyei Jogú Város Polgármesteri Hivatalának statisztikai adatgyüjteménye alapján, 2009). A tulajdonképpeni veszélyt az önellátásra szoktatott kutyák és a mindent eltaposó legelő jószág jelenti. A kutyák riasztják, és ha úgy adódik el is pusztítják a fészkelö tyúkot, elfogyasztják a fészekalj tojásait vagy a még repülni nem tudó csibéket (SzABÓ, 2003). A legelő jószág a taposással tesz tönkre mindent, ami útjába kerül (SzABÓ, 2003). Mivel a rendszeres, mindennapi legeltetés az erdős területek szomszédságában történt, az állatokat védelmező kutyák rendszeresen bejártak az erdőszegélyébe vagy a mélyebben fekvő területekre. Így folyamatosan fennállt annak a veszélye, hogy zaklatták a császármadarakat vagy akár el is pusztították azokat (SzABÓ, 2003). A másik szorosan kötődő jelenség a jószágok terelése egy adott területről egy előre meghatározott célpont irányába, amely lehet akár egy nyári szállás vagy akár lakott település is. Ilyenkor a tetemes kárt idéznek elő a taposással és a fel-alá rohangáló kutyafalkával, amely a terelt jószágot követi (SzABÓ, 2009). Az eddigi tapasztalatok azt mutatják, hogy az 1999-től még növekvő tendenciát mutató tevékenység 2004-re megtorpant. A növekvő fajlagos beruházási költségek és az emelkedett ráfordítások miatt csökkent a jövedelem, minek következtében 2005-ben már csak két juhnyáj létezett a két pusztán (Csíkszereda Megyei Jogú Város Polgármesteri Hivatalának statisztikai adatgyüjteménye alapján, 2009). Az évtized utolsó harmadában megnehezültek az értékesítés lehetőségei. Egyes állati termékek leértékelődtek, időközben exportra eladhatatlanná váltak. Mindezek után 2008-tól egészen napjainkig csak egy hivatalosan bejegyzett juhnyáj létezik az I.-es mintaterület szomszédságában (Csíkszereda Megyei Jogú Város Polgármesteri Hivatalának statisztikai adatgyüjteménye alapján, 2009).

A II.- es mintaterület közvetlen szomszédságában nem folytattak az 1989-et követően állattartással kapcsolatos tevékenységeket (Csíkcsicsói Polgármesteri Hivatal statisztikai adatgyüjteménye alapján, 2009).

A fentiek függvényében a legeltetés problémát jelent a császármadarak esetében, mert e madarak az év legnagyobb részében ugyanazon a területen belül tartózkodnak (COTTA et al, 2001). Ezek szerint mind a legeltetés mind pedig a terelés zavarja e területeket, minek következtében az amúgy is agyonbolygatott populációk egyedei teljesen elhagyják addigi otthonterületeiket, máshol keresve menedéket (SZABÓ, 2003).

\subsubsection{A fakitermelések hatása}

A rendszerváltást követően Romániában is elkezdődött a mezőgazdasági területek és erdők tulajdon jog szerinti rendszerezése és birtokba helyezése. Az erdők visszaszolgáltatása két nagy szakaszba került kivitelezésre, elsőként a 18/1991-es törvény értelmében, míg másodszor az 1/2000-es törvény elöírásai alapján.

Hargita megyében a 207354 hektárnyi erdővel borított területből a 18/1991-es törvény értelmében visszaszolgáltattak jogos tulajdonosainak 21218 hektár erdőt. Az 1/2000-es törvénynek megfelelően visszakerültek régi tulajdonosaik birtokaiba a nagy kiterjedésü erdővel borított területek is, összesen 182057 hektár. A restitúció következtében ezek az erdős területek felaprózódtak, minekutána újra üzemterveztették tulajdonosaik az elkövetkezendő erdőgazdálkodás érdekébe. 
Gyakorlatilag az erdőknek 87,8\%-a került magánkézbe. A nagykiterjedésü összefüggő erdős területek jogilag megszüntek, majd ezt követően elkezdődtek az erdőkitermelések. Egy időben több helyen kisebb-nagyobb intenzitással folytatódtak ezek a munkálatok, ami viszont nem jelenti azt, hogy megnövekedett a kitermelt famennyisége is az 1989 elötti időszakokhoz képest. Inkább a folyamatos zavarásról beszélhetünk a felaprózott vágásterek következtében, ami a császármadár állományokban közvetlenül vagy közvetve változásokat idézett elő.

$\mathrm{Az}$ egyszerüsítés érdekébe ezeket a változásokat a továbbiakban nem az egész megye területén vizsgáltam, hanem a korábban kiválasztott két mintaterületen belül. Éppen ezért, elsőként a Csíkszeredai Erdészeti Hivatal erdővel borított területeinek változását mutatom be az alábbiakban. A 17697 hektáros erdőterületből jelenleg az állam tulajdonát képezi 670 ha (3,79\%) (HME, 2009). Az erdőterületeket egy állami és egy magán erdészeti hivatal kezeli.

A tulajdonviszonyok változása következtében a gazdálkodás feltételei is megváltoztak. Ez a körülmény eredményezte a felaprózott vágásterek megjelenését a néhány tized ha-tól a 10-15 ha-ig. A két mintaterület esetében az erdőhasznosításoknak köszönhetően a biotópok képe hónapról hónapra változott negatívan befolyásolva a mindenkori élőhely szerkezeteket. Az erdőhasznosítási állapotokat rögzítő adatok elemzése megmutatja, hogy a két mintaterület az utóbbi tíz évben több alkalommal vált különböző erdőhasznosítási tevékenységek színterévé.

Az I. mintaterület kiválasztott három biotópja összesen 65,90 ha. Az 1999-2009 közötti időszakba ezek a területek közvetlenül vagy közvetve érintve voltak a hasznosítási munkálatokkal, mert csak a mintaterületen belül az erdőhasznosítások összesen 687,6 ha-on viszonylag magas értéket mutatnak $\left(3811 \mathrm{~m}^{3}\right)$. 1999-ben 164,4 ha-on végeztek erdőhasznosítást $\left(23,9 \%\right.$ és $\left.191 \mathrm{~m}^{3}\right)$. Az általános tendencia azonban a fokozatos növekedést mutatja, 2005-ben 176,9 ha-on volt a maximum $\left(25,7 \%\right.$ és $\left.1014 \mathrm{~m}^{3}\right)$. A minimum 2003-ban volt, amikor erdőhasznosítási munkálatokkal csak 8,6 ha-os területet érintettek $(1,25 \%)$. A fentiek alapján az I.-es mintaterületen a császármadár állomány alakulását kezdetben a tulajdon és gazdaságszerkezet változás nem nagymértékben befolyásolta. Azonban a fokozatosan növekvő erdőhasznosítások, az elhúzódó,- hosszantartó közelítő munkálatok ugyanazon az erdőtagokon belül a 2009-es év végére változásokat idéztek elő az itt élő populációkba. Az 1-es biotóp, amely a 16-os erdőtagon belül volt korábban kijelölve, folyamatos zavarásoknak volt kitéve az azt körülvevő erdőtagokban történő erdőhasznosítások következtében. A császármadarak teljesen eltűntek erről az élőhelyről, remélhetőleg új területre lelve valamelyik távolabbi, ember által nem zaklatott területen. A 2es biotóp 20-as erdőtagja a legkevésbé volt zavarásnak kitéve. Értékesítési munkálatokat végeztek a szomszédos kaszálókon és legelőkön, amelyek következtében a kitermelt faanyagot más területeken keresztül szállították a felhasználóhoz. Az itt létező császármadár populáció megvan. A 3-as biotóp a 21A és 22A erdőtagokban volt kijelölve. Értékesítéssel ez a terület is érintve volt, de nem számottevően. A folyamatos hasznosítások e területtől távolabbra eső erdőtagokban történtek, minek következtében a császármadarak nem hagyták el ezen élőhelyet. Létezésüket a 2009-2010-es megfigyelések alátámasztják.

A II. mintaterületen a korábban is megfigyelt élöhelyek összesen 40,4 ha-on találhatók. Ezek a területek az utóbbi tíz évben közvetlenül érintve voltak az értékesítési munkálatokkal. A kitermelések kiterjedtek a mintaterület teljes nagyságára, a közeli és távolabbi erdőtagokra, valamint a közelben levő (beerdősülő) kaszálókra is. Az 1999-2009 közötti időszakban ugyanazon erdőtagokon belül több alkalommal is végeztek erdőhasználati munkálatokat, ami összesen 911,9 ha-t érintett. Összességében az erdőhasznosítások nagyon magas értéket mutatnak 14 484,2 $\mathrm{m}^{3}$-t tettek ki. Ezzel szembe 1999-ben 48,9 ha-on (5,36\% és $100 \mathrm{~m}^{3}$ ) végeztek fakitermelést, ami a tíz éves időszak legalacsonyabb értékének felel meg. Az általános tendencia azonban a kettes mintaterület esetében is a haszonvétel fokozatos 
növelése volt. A maximum 2005-ben 277 ha-on (30,37\% és 1000,2 $\mathrm{m}^{3}$ ) és 2007-ben 189 haon volt $\left(20,72 \%\right.$ és $\left.5536 \mathrm{~m}^{3}\right)$. Az adatok azt mutatják, hogy a folyamatos zavarások egyformán érintették mind a három biotóp madarait. A kezdeti (1999-2004 között) kisebb mértékü erdőhasznosításokat 2005-től kezdődően nagyméretü munkálatok váltották fel, amelyek következtében a császármadarak kivándoroltak a korábban vizsgált három biotóp területéről. A vadőri megfigyeléseknek köszönhetően legközelebb a kettes mintaterülettel szomszédos vadásztársulat dél-nyugati kitettségü területein a bükkösök szomszédságában azonosítottak császármadarat, ami légvonalban is több kilométernek fele meg.

A fentiek alapján, a két mintaterületen a császármadarak számára a tulajdon és gazdaságszerkezet változás kezdetben nem jelentett különösebb veszélyt. Az ismétlődő és méreteiben növekvő értékesítések az utóbbi négy évben negatívan hatottak az itt létező császármadár populációkra, melynek következtében csökkent állományuk.

A tervszerü fakitermelések mellett tetemes széldöntéseket és széltöréseket, mint abiotikus tényezők káros hatását feltétlenül meg kell említeni. Hargita megye területén az utóbbi 10 év leforgása alatt több alkalommal történt nagymértékü, szél által okozott kár, amely után több ezer hektáros erdöterület semmisült meg. Ilyen volt az 1995. november 5-i, vagy a 2002. március 7-i széldöntés. Ezek a jelenségek tulajdonképpen azonnali élőhely változást idéznek elő. Megsemmisültek az erdőszegélyek, tönkrement a cserjeszint, a hatalmas erdőállományok - a kényszer-fakitermelések következtében - teljesen eltüntek. Mindezek következtében a területéhez ragaszkodó császármadár is kénytelen volt más otthont keresni magának. A szélkárok következtében meginduló fakitermelési munkálatok 4-5 évig is eltarthatnak, ami ugyanilyen idejű tartós zavarást jelent, és aminek következtében a környék növénytársulásai teljesen megváltoznak. Ahhoz, hogy a császármadárnak ismét otthont adó vegetáció alakuljon ki, ahhoz sok évnek vagy akár évtizednek kell eltelnie.

\subsubsection{A rekreációs tevékenységek hatása}

A legeltetés, állatterelés, erdökitermelés, tehát a munka mellett a ma embere egyre többet kirándul, gombát, erdei gyümölcsöt gyüjt, sportol, vagy éppen pihenóhelyet épít ki magának az erdők közvetlen szomszédságában. A kiránduló emberek zajosak, lármásak és nagyon sokszor felelőtlen magatartásról tesznek tanúbizonyságot. Nem ismervén a császármadarak földre épített fészkeit, könnyen tönkre teszik azt, vagy zavarják az ott fészkelő madarakat, felborítva megszokott életvitelüket, a számura nélkülözhetetlenül fontos csendet (COTTA et al, 2001).

A közúti motorozás régi fogalom. Apáink, nagyapáink szívesen elmotorozgattak klasszikus motorkerékpárjaikkal naphosszakat anélkül, hogy zavarták volna az élővilágot, mindennapi környezetüket. Mára ez a fogalom teljesen megváltozott és mire észbe kapott az itteni társadalom, divatos terepmotorok lepték el az egész környéket. Hatalmas hangerővel összejárják a havasi legelőket, rendszeresen bejárnak az erdőállomány szegélyébe, vagy akár a mélyebben fekvő területekre is. A motorozás e változata hétköznapokon, de föleg hétvégenként ölt hatalmas méreteket. Ennek következtében az egyébként más, negatívan ható antropogén tevékenységektől mentes területeken is zaklatásnak, folyamatos zavarásnak vannak kitéve a császármadarak. Mindezek következtébe a madarak elvándorolnak addigi élőhelyükről vagy akár el is pusztulhatnak. Mindez azért jelent problémát, mert e madarak az év legnagyobb részében ugyanazon területen belül tartózkodnak. E populációk egyedei a zavarás okán teljesen elhagyják addigi életterüket, máshol keresve menedéket, magasabb régiókban vagy a teljesen zavartalan, távolabbi, ismeretlen erdőzugokban.

A motoros hószánkózás a zavaró tényezők egy másik újabban kialakult formája, amely negatívan hat a császármadár populációira. A hóvárakra és az egybesereglett 
császármadarakra közvetlen veszélyt jelentenek. Nagykiterjedésủ területeket járnak be óriási zajjal, lármával. Eleinte csak a nyílt területeken hószánkóztak és kis létszámba, de mára ez a jelenség nagy méreteket öltött, behatolva az erdőállományokba, nyiladékokba és még a patak menti területekre is. A telelő madarakat megriasztják, minek következtében szétszélednek, könnyü prédává válva a ragadozóknak és a hosszan tartó fagynak. A negatív antropogén tényezők eme formája egyre inkább nő, és mind nagyobb területeket érint, tönkre téve az addigi hagyományos és sikeres császármadár telelöhelyeket.

Az 1990-es évektől kezdődően a megváltozott tulajdonjogi viszonyoknak köszönhetően az erdei építkezések intenzitása is fokozódott. Az erdőkitermelések és hétvégi nyaralók új utak megépítését követelték, aminek következtében kavicsos és földutakat létesítettek.

A kavicsos utak jelentik a folyamatos erdőgazdálkodás biztonságát. Magas teherbíró képességűek, időjárás állóságuk mindennek a záloga. Folyamatosan karbantartják és javítják szerkezetüket. A földutakat kimondottan a finomfeltáró hálózat kialakításakor építették, amelyek nagymértékben megsértették az aljnövényzetet alkotó cserjeszintet és a lágyszárúakat. Az I.-es mintaterület esetében elenyésző ezen létesítmények aránya, míg a II.es mintaterület esetében a folyamatos erdőkitermelések következtében teljesen behálózzák a kiválasztott területet és nap, mint nap használatnak vannak kitéve. Az utakhoz tartozó útpadkák a mintaterületek szomszédságában elhanyagoltak és azok növényborítottsága hiányos.

A hétvégi házak építése fokozatosan növekedett az 1990-es évek után. Míg 1999-ben az I.- es mintaterület 1-es biotópja közelében nemlétezett ilyen jellegü létesítmény, 2009-re 18 hétvégi nyaralót építettek. Ezen létesítmények kimondottan a pihenés és kikapcsolódás érdekébe készültek, aminek következtében nagy tömegeket vonzanak a környékre. A II. - es mintaterület közvetlen szomszédságában is épültek hétvégi nyaralók. 1999-ben a környéken csak három időszakos nyári szállás létezett, valamivel távolabb egy nagyobb nyaralóval. Ezzel szembe az utóbbi tíz évben tizenegy nyaraló épült fel, ember tömegeket csábítva a környékre. A fentiek alapján a kiépített úthálózat valamint az modern épületek sokasága ember tömegeket vonz a mintaterületek környékére. Összességében elmondható, hogy a ma embere az építkezésekkel végérvényesen megváltoztatja az erdö ökoszisztémáját, aminek következtében, ha indirekt módon is, de negatívan befolyásolja a császármadár állományt.

\subsubsection{A predáció}

A sok ragadozó faj közül, amelyek megtalálhatók Hargita megye területén, jelen munkában csak azokat soroljuk fel. amelyek potenciális veszélyt jelentenek a császármadarak számára. Mindezek állományjellemzéséhez felhasználtuk az 1999-2009 közötti években történt állomány felméréseket, valamint a vadászat útján történt hasznosításokból származó adatokat. Bár ismertek a borz (Meles meles), a farkas (Canis lupus), a vadmacska (Felis silvestris), a hiúz (Lynx lynx), a nyuszt (Martes martes) és a barnamedve (Ursus arctos), a róka (Vulpes vulpes) és a vaddisznó (Sus scrofa) állomány és elterjedési adatait (SZABÓ, 2013), ehelyütt mégis csak az utóbbi kettő ú. n. kulcspredátor faj hatásait értelmezzük.

A róka (Vulpes vulpes) populáció nagyságának meghatározása elégé nehéz és körülményes dolog. Különösképpen a két mintaterületen történő felmérés lehetetlen, mert nem léteznek kotorékok az adott helyeken, ugyanakkor számolni kell a szomszédos területekről való bevándorlással. Éppen ezért a rókaállomány nagyságának a vizsgálatát a megye teljes területén próbáltam összegezni az 1999 és 2009 közötti időszakban. Ez a művelet a vadőri munka alapján vált csak lehetővé. A felmérések az átmeneti és alakalmi előfordulásokat jelenítik meg. A feltüntetett róka elöfordulások bizonyítják a legjobban azt, 
hogy az állandó és alkalmi császármadár populációk előfordulási helyén megtalálhatók ők is, mi több jelentős veszélyt jelentve e madárfaj állomány nagyságát illetően. Itt érdemes említést tenni a megye területén a 2000-ben és 2001-ben, valamint a 2005-2006 közötti időszakban tomboló veszettségről, amely keményen megtizedelte a vörös róka populációkat, csökkentve az újabb betelepülések esélyét és ily módon a császármadár számára veszélyt jelentő predátor állomány sürüségét is egyben. A róka állománynagyságának alakulására az 1999 és 2009 közötti években 19,6\%-os növekedés (316 egyed) volt a jellemző. Az így megfigyelt egyedekből 2009-ben összesen 407 példányt hasznosítottak, ami viszont 26\%-al alacsonyabb az 1999-ben hasznosított 550 példánynál (7. táblázat) (HME, 2009).

\section{7. táblázat: A császármadár, a róka és a vaddisznó becsült állománynagysága és terítéke} Hargita megye területén 1999-2009 között (HME, 2009)

Table 7: Estimated population size and bag size of Hazel Grouse, Red Fox and Wild Boar in Hargita County, 19992009 (HME, 2009)

\begin{tabular}{|c|c|c|c|c|c|c|}
\hline \multirow{2}{*}{$\begin{array}{l}\mathbf{E} \mathbf{v} \\
\text { Year }\end{array}$} & \multicolumn{2}{|c|}{$\begin{array}{c}\text { Császármadár } \\
\text { Hazel Grouse }\end{array}$} & \multicolumn{2}{|c|}{$\begin{array}{c}\text { Róka } \\
\text { Red Fox }\end{array}$} & \multicolumn{2}{|c|}{$\begin{array}{l}\text { Vaddisznó } \\
\text { Wild Boar }\end{array}$} \\
\hline & $\begin{array}{l}\text { egyedszám } \\
\text { individuals }\end{array}$ & $\begin{array}{c}\text { hasznosítás } \\
\text { bag size }\end{array}$ & $\begin{array}{l}\text { egyedszám } \\
\text { individuals }\end{array}$ & $\begin{array}{c}\text { hasznosítás } \\
\text { bag size }\end{array}$ & $\begin{array}{l}\text { egyedszám } \\
\text { individuals }\end{array}$ & $\begin{array}{c}\text { hasznosítás } \\
\text { bag size }\end{array}$ \\
\hline 1999 & 1425 & 49 & 1930 & 550 & 1593 & 190 \\
\hline 2000 & 1450 & 36 & 1817 & 547 & 1677 & 283 \\
\hline 2001 & 1680 & 48 & 1922 & 342 & 1741 & 467 \\
\hline 2002 & 1685 & 49 & 1255 & 535 & 2014 & 536 \\
\hline 2003 & 1800 & 56 & 1894 & 630 & 2020 & 516 \\
\hline 2004 & 1925 & 23 & 1731 & 610 & 2337 & 668 \\
\hline 2005 & 1780 & 5 & 1804 & 688 & 2784 & 796 \\
\hline 2006 & 1700 & 0 & 1820 & 455 & 3018 & 932 \\
\hline 2007 & 1600 & 0 & 1661 & 444 & 2964 & 719 \\
\hline 2008 & 1470 & 0 & 1770 & 407 & 3031 & 911 \\
\hline 2009 & 1550 & 0 & 1514 & 407 & 3067 & 480 \\
\hline
\end{tabular}

Ha a 10 éves eredményeket értékeljük, kiderül, hogy a császármadárra a róka egész évben veszélyt jelent úgy a párzás, fészkelés ideje alatt, mint a csibe nevelés és telelés ideje alatt is (SZABÓ, 2003).

A vaddisznó (Sus scrofa) a megye területén mindenhol előfordul. Egy terjeszkedőben levő fajról lehetett beszélni, amely jelenség a mezőgazdaság által nyújtott kedvező feltételekkel, valamint a korszerü vadgazdálkodással magyarázható. A méreteiben felaprózódott mezőgazdasági területekröl a vaddisznó bizonyos arányba visszaszorult az erdőkbe. Csak esős idő után keresik felé a réteket, legelőket giliszták után kutatva (FARAGÓ, 2002). Lévén mindenevő, egész évben szüksége van az állati eredetü táplálékra. Ehhez részben turkálással, dögevéssel vagy ragadozással jut hozzá. Itt jön számításba a tojás, fióka és madárevés, amely a tulajdonképpeni veszélyt jelenti a császármadár populációkra is. A vaddisznó gyakori ugyanott, ahol a megye területén a császármadár állandó vagy alkalmi elöfordulását jelezték a vadőrök. Köztudomású az a tény, hogy a vaddisznónak állati eredetü táplálékra is szüksége van. Madarak a vizsgált rókagyomrok 5\%-ában fordultak elő (FARAGó, 2002), éppen ezért fennáll annak a valószínűsége, hogy zavarják a császármadarakat, és ha lehetőség van rá, felfalják a földön talált császármadártojásokat, vagy a frissen kikelt fiókákat (SZABÓ, 2003). A vaddisznó állomány nagyságát nyilvántartó adatok szerint (7. táblázat), 
Hargita megye területén 1999-2009 közötti időszakban a becsült állomány 48\%-os növekedését mutatták ki. Ami a hasznosítást illeti közel 80\%-os növekedést értek el 1999-hez képest, ami 721 példánnyal több egyed kilövését jelentette (HME, 2009). Ezek a számadatok végül is egy egész megye területére vonatkoznak, még ha növekedést is mutatnak, nem jelentenek olyan nagy sűrüségű vaddisznóállományt, hogy az a császármadár populációkat bizonyítottan veszélyeztetné. Igazán komoly veszélyt a vaddisznó tömeges megjelenése jelentene, amikor is a magas állomány sürüség és a relatív táplálékhiány együttesen érzékenyen befolyásolná a császármadarakat (CZÁJLIK, 1979).

\subsection{A császármadár állomány védelme}

Felmerül a kérdés, mit tehetünk a császármadár védelme érdekében, hiszen a felerösödött erdőhasználat, legeltetés, turizmus, építkezések, nyári és téli technikai sportok, s kis mértékben a vadászat is, mind zavaróbban hatnak életfeltételeire. Kézenfekvőnek tünik az a megoldás, hogy az erdészeti hatóságok és a fakitermelő egységek egy olyan közös megállapodást hozzanak létre, amelynek eredményeként valamelyest elkezdenék rendszerezni a nagy kiterjedésü erdöhasználati munkálatokat. Bizonyos területeken belül - a vadászati és vadgazdálkodási szakemberek véleményét figyelembe véve - próbálják elökészíteni a kitermelési munkálatokat, hogy ezen tevékenységeken keresztül ne zavarják a vadat.

Egy másik fontos problémának a megoldása még várat magára. A legeltetések okozta károk még mindig léteznek. Hiába van a kutya nyakában kolonc, attól még tudja riasztani a madarakat, vagy felfalni a tehetetlen kiscsibéket. A pásztorkutyák kövessék a nyájat vagy a marhacsordákat, a pásztorok ügyeljenek arra, hogy ne több száz méteres körzetben kóboroljanak, miközben kísérik a jószágot.

Tudjuk mit jelent a taposási kár, és hogy mint jelenség újból terjedőben van. Mi a teendő ezen faj védelmét illetően? Szintén a fokozott párbeszéd alkalmazása. Meg kell értetni az érintett személyekkel, hogy van időszak, amikor a legeltetésre jobban oda kell figyelni, és hogy nincs keresnivalójuk a legeltetett állatoknak az erdövel borított területeken és azok közvetlen szomszédságában. A legeltetés céljára jól meghatározott területek léteznek, amelyekért bért fizetnek, tehát akkor ezeket kell hasznosítani. Ha mindez nem így történik, akkor a büntető törvényeket alkalmazni kell.

A turizmus, mint jelenség egyre jobban terjedőben van. Az emberiségnek alapvető joga, hogy a természetet járja, azt nem lehet megtiltani. Viszont nevelni, tanítani lehet és kell is arra, hogy ne károsítja az erdőt és benne élő állatfajokat. Ne tegyék tönkre a megtalált fészkeket és ne zavarják a madarakat. Ha mindenképpen megfigyeléseket akarnak folytatni, vagy fényképeket és videofelvételeket szeretnének készíteni, kérjék ki a szakavatott vadászok véleményét annál is inkább, mert a megfelelő szaktanácsok és módszerek alkalmazása mellett sokkal eredményesebb lesz a próbálkozás. Ma ezt szervezett ökoturizmusnak hívjuk.

A császármadár állományt veszélyeztető közvetlen tényezők mellett a legnagyobb veszélyt az élöhelyek beszükülése, megszünése jelenti. Tulajdonképpen arról van szó, hogy az első látásra hatalmas kiterjedésünek tủnő havasok világában mégis csak fogy a császármadarak élőhelye. Mindez az emberi tevékenységekkel magyarázható, amely fokozatosan rányomja bélyegét az egész Kárpátokat borító erdőségekre. Hiába történnek nagyfokú erdősítések, mert éveknek vagy évtizedeknek kell eltelni ahhoz, hogy a faj, megint otthonra találjon egy adott területen belül. Jóllehet néhány évtized alatt a megváltozott új külsőt öltő élettér valamelyest hasonlít az eredeti formához, azonban a megzavart, szétszóródott populációk már máshol találtak menedéket, megfelelö életteret. Ha ez nem sikerült nekik, akkor sajnos lassanként felmorzsolódtak. Egy hatalmas területen történő erdőhasznosítás, vagy nagyméretü 
széldöntés, amely akár százhektáros területet is tönkretehet, az ott tartózkodó populációt nagy valószínüséggel két vagy még több részre osztja. Ezen részpopulációk átcsoportosulnak vagy teljesen elszigetelődhetnek egymástól. A sokáig magányosan maradt populációk törzsállománya lassan csökkeni kezd, és fokozatosan kipusztulnak, ami az összlétszámban is fogyatkozást jelent. Az ilyen hatásokat nehezen és sok idő elteltével tudja egy adott populáció kiheverni, amit ha lehetséges, meg kell előzni vagy legalábbis meg kell próbálni megelőzni.

Az élőhelyi körülmények javítása érdekében fontos lenne az, ha a császármadár élőhelyeit valamilyen formában megpróbálnánk védettebbé, legalábbis különlegesen kezelt területekké nyilvánítani. Értem ez alatt azt, hogy a fakitermelési munkálatokat megfelelő helyen és megfelelő időben végezzék el. Itt hárulna fontos feladat az Erdészeti Felügyelőségekre, hogy az elöirányzott munkálatokat kimondottan az üzemterveknek megfelelően végezzék el, kezdve a nevelö-ápolási munkáktól egészen a véghasználatokig. Minderre azért van szükség, mert csak így lehet megfelelően időtálló, szabályos szerkezetủ erdőállományokat kialakítani, hogy dacolni tudjanak a szeszélyes abiotikus és biotikus viszontagságokkal, valamint így lehetne megelözni a hatalmas szélkárokat, vigyázva a gazdag cserjeszintre is, mely nagyon fontos az utódnevelés és telelés szempontjából.

Fajvédelemről lévén szó megemlíthető a császármadár zárttéri tenyésztésének lehetösége is. Ennek során tulajdonképpen a mentett fészkek fiókáinak a nevelésétől és a későbbiek során a természetes élőhelyekre való visszajuttatásukról kellene gondoskodni. A világban kidolgozták már a galléros fajd (Bonasa umbellus), a siketfajd (Tetrao uragallus) és a nyírfajd (Tetrao tetrix) zárttéri tenyésztésének technológiáját. A tenyésztett madarak repatriációját különösen olyan területeken lehet alkalmazni, ahol a faj már eltünt. Semmi esetre sem kerülhetők meg ez esetben sem mindazon megelőző intézkedések, amelyet a természetes populációk védelmében foganatosítani szükséges, különben eredménytelen lesz minden telepítési kísérlet.

Összefoglalva elmondható, hogy a zavartalan életkörülmények biztosítása, az etikus vadászat, a vaddisznó és a ragadozók megfeleló állományszinten való tartása biztosítja a védelmet a császármadár számára (SzABó, 2003).

\section{5. ÖSSZEFOGLALÁS}

A ragadozó fajok mellett a legnagyobb veszélyt a császármadár populációkra az élőhelyek beszükülése, megszünése jelenti. Tulajdonképpen arról van szó, hogy az első látásra hatalmasnak tünő havasok világában mégis csak fogy a császármadarak élőhelye. Mindez az emberi tevékenységekkel magyarázható, mely fokozatosan rányomja bélyegét az egész Kárpátokat borító erdőségekre. Hiába történnek nagyfokú erdősítések, mert éveknek vagy évtizedeknek kell eltelnie ahhoz, hogy ezen csend és magányt kedvelö madárfaj, megint otthonterületet alakítson ki magának egy adott területen belül. Jóllehet néhány évtized alatt a megváltozott új külsőt felöltő biotópok valamelyest hasonlítanak eredeti formájukhoz, azonban a megzavart, szétszóródott populációk már máshol találtak menedéket, megfelelő életteret. Ha ez nem sikerült nekik, akkor sajnos lassanként felmorzsolódtak. Egy hatalmas területen történő erdőhasznosítás, vagy nagyméretü széldöntés, amely akár száz hektáros területet tesz tönkre, az ott tartózkodó populációkat nagy valószínüséggel két vagy még több részre osztja. Ezen részpopulációk átcsoportosulnak, vagy teljesen elszigetelődhetnek egymástól. 
A sokáig magányosan maradt populációk törzsállománya lassan csökkeni kezd, és fokozatosan kipusztulnak, ami az összlétszámban is fogyatkozást jelent. Az ilyen hatásokat nehezen és sok idő elteltével tudja egy adott populáció kiheverni, amit ha lehetséges meg kell elözni vagy legalábbis meg kell próbálni.

\section{KÖSZÖNETNYILVÁNÍTÁS}

Kutatásaim támogatásáért ezúton mondok köszönetet a Nyugat-magyarországi Egyetem Vadgazdálkodási és Gerinces Állattani Intézet igazgatójának, Dr. FARAGÓ SÁNDOR professzor úrnak. Köszönöm a Csíkszeredai Erdészeti Hivatal dolgozóinak támogatását valamint azt, hogy megteremtették a vizsgálatok és felmérések elvégzéséhez szükséges feltételeket.

Végezetül köszönöm MARA ÁRPÁD tanár úrnak (Csíkszereda), hogy szaktudásával, tapasztalatával segített, amely nélkül e munka nem születhetett volna meg.

\section{IRODALOMJEGYZÉK}

COTTA V., BodEA, M. \& Micu, I. (2001): Vânatul şi Vânătoarea în România. Editura Ceres, Bucureşti

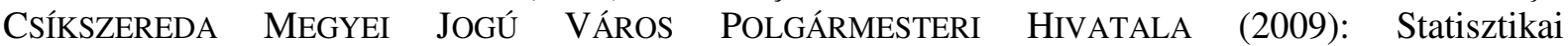
adatgyüjtemények.

CzÁJLIK P. (1979): A császármadár (Tetrastes bonasia) az Északi Középhegységben. Fol. Hist.-Nat. Mus. Matr. 5: 107-127.

CZÁJLIK P. (1981): Adatok a császármadár (Tetrastes bonasia) tollazatának és tollváltásának ismeretéhez. Fol. Hist.-Nat. Mus. Matr. 7: 103-116.

CZÁJLIK P. (1981): Etológiai vizsgálatok a mátrai császármadár (Tetrastes bonasia) populációkban. Aquila 88: 31-54.

FARAGó S. (1997): Élőhely fejlesztés az apróvad gazdálkodásban. A fenntartható apróvadgazdálkodás környezeti alapjai. Mezőgazda Kiadó, Budapest

FARAGÓ S. (2002): Vadászati állattan. Mezőgazda Kiadó, Budapest

HME (2009): Hargita Megyei Erdőfelügyelet. Statisztikai adatgyüjtemények.

IVANTER, E. V. (1962): Zur Biologie des Haselhuhns in Karelien. Ornitologia 4: 87-98.

KlemM, W. \& KoHL, S. (1988): Die Ornis Siebenbürgens. Böhlau Verlag, Köln, Wien, 469 p.

SZABÓ I. (2003): A Csíki-havasok császármadár (Bonasa bonasia) állományának vizsgálata. BSc. Szakdolgozat, Nyugat-magyarországi Egyetem, Erdömérnöki Kar, Sopron.

SZABÓ I. (2009): Vizsgálatok a Csíki-havasok császármadár (Bonasa bonasia) állományának változásáról az elmúlt 10 évben. MSc. Szakdolgozat, Nyugat-magyarországi Egyetem, Erdömérnöki Kar, Sopron.

SZABÓ I. (2013): Néhány vadgazdálkodási szempontból fontos madár- és emlősfaj elterjedése Hargita megyében. Magyar Apróvad Közlemények 11: 227-240. 